\title{
LA RIOJA A COMIENZOS DE LA EDAD MODERNA
}

\author{
Jose Luis Gómez Urdáñez*
}

\begin{abstract}
RESUMEN.- Este artículo sintetiza los más destacados aspectos de la economía, sociedad e instituciones de La Rioja durante el siglo XVI. Analizamos el notable desarrollo económico y dinamismo social, producto de las actividades comerciales de la burguesía mercantil de una ciudad en la que el tráfico de la lana a través de los puertos del Cantábrico con Flandes, y el comercio del vino con el País Vasco, produjeron una mentalidad especulativa e interesantes transformaciones sociales.
\end{abstract}

SUMMARY.-This paper synthesizes the most relevant aspects of the economy, society and institutions of La Rioja in the 16th Century. In it we see the remarkable economic developement and society dinamism, resulting from the business activities of city-dwellers who traded with wool and wine.

\section{PRELIMINAR}

El autor, responsable de un proyecto de investigación colectivo, es deudor de aquellos a los que inició en la investigación - y de los que tanto les influyeron en la universidad aragonesa, como Forcadell, Carreras, Longares - a los que no sólo debe buena parte de lo que aquí se expone; más importante aún: los jóvenes modernistas riojanos le han proporcionado la satisfación de lograr un equipo en la universidad, objetivo siempre solicitado por los historiadores, pero difícilmente alcanzable en nuestra competitiva e individualista universidad. $Y$ un equipo duradero. Sin que todavía podamos explicarlo bien, aquí, en Logroño se logró esa "época dorada" de

\footnotetext{
* Profesor del Departamento de Ciencias Humanas y Sociales, área Historia Moderna, Universidad de La Rioja.
} 
los hombres, cuando no había tuyo y mío, como soñaba Cervantes que alguna vez pudo ocurrir; esa inmensa fortuna -más áun en los tiempos que corren- es mi mayor deuda. Deseo por eso hacer explícito mi agradecimiento a los doctores Jesús Javier Alonso Castroviejo, Pedro Luis Lorenzo Cadarso, hoy profesor en la Universidad de Extremadura, Francis Brumont —un gran profesional de la Universidad de Toulouse, al que tanto debemos-; a los doctorandos Santiago Ibáñez, cuya tesis será defendida en la UR antes de que estas páginas vean la luz, Noemí Armas, Gregorio Torrealba, Ana Mendióroz, Francisco M. Burgos y Ramón Moreno, profesor en la Universidad de Huelva. Angela Atienza, compañera en el área y en las lides universitarias, ha enriquecido el manuscrito y ha contribuido a orientar los debates hacia temas que nos pasaban desapercibidos.

También somos deudores de otros estudiosos de la historia de La Rioja, cuyo valor se reconoce en sus magníficas aportaciones a la Historia de la Ciudad de Logroño: los conocidos Merche Lázaro y Pedro Gurría, que han llegado a saberlo todo sobre la demografía riojana, y que han expuesto en sus libros casi todos los datos que manejamos sobre la población riojana. El autor sólo ha intentado sintetizar sus aportaciones y relacionarlas con las que provienen de fuentes cualitativas de otra esfera que la demográfica. Los trabajos, afortunadamente ya publicados, de Angeles Cristóbal, la gran investigadora de la Inquisición en la Historia de Logroño, han proporcionado una visión más amplia y renovadora sobre el Tribunal, sobre sus miembros y sobre sus métodos de actuación en medio de la "mentalidad inquisitorial" que ha sabido descubrir en las estructuras internas del Tribunal de Logroño.

\section{El GRAN Siglo de LA RioJa}

La fase expansiva que conoció el Occidente europeo desde mediados del siglo XV alcanzó a Castilla, especialmente tras los conflictos bélicos intrapeninsulares, a cuyo fin la monarquía, una vez más, salía robustecida. Granada, las plazas del norte de Africa, Canarias, y luego Navarra, acompañaron, como triunfo militar y exhibición de la nueva legitimación monárquica, el momento culminante del expansionismo castellano, logrado en realidad en una coyuntura económica, interior e internacional, que no dejó de ser favorable hasta el último tercio del siglo XVI. La empresa americana supondría la coronación del éxito por vía publicitaria, bien que luego contribuiría a sostener el dominio de mundo, a base de la plata importada.

Un crecimiento demográfico sostenido desde fines del XV, junto a la reactivación de la economía, volcada al exterior aún antes del impacto de la plata americana, fueron los soportes del esplendor castellano. La Rioja, tierra de frontera, tenía al inicio del proceso los elementos necesarios para participar ventajósamente en el gran siglo castellano: hombres y riqueza.

$\mathrm{Al}$ comienzo de la Edad Moderna, La Rioja es un mundo de señores y campesinos, con pequeñas ciudades enclavadas en un mundo feudal y agrario, de población diseminada en aldeas y pequeños pueblos. Señorializada en gran parte casi desde la 
reconquista cristiana, el dinamismo social y las expectativas de cambio sólo se adivinaban en algunas ciudades, pero incluso en ellas dominaba la inmovilidad. La transformación de "usos y costumbres", sacralizados, producía temor. Los grandes cambios se producían a causa de fenómenos cuyos mecanismos no conocían: la guerra, las enfermedades, las catástrofes naturales. Era la Rueda de la Fortuna, la rueda de Jorge Manrique "presurosa/ la cual no puede ser una/ ni estar estable ni queda".

Sin embargo, en el primer siglo Moderno, la fisionomía de La Rioja cambió extraordinariamente. A fines de la centuria, muchas ciudades habían doblado su población; los modos de vida se habían diversificado, en las ciudades había aumentado el número de vecinos que no vivían de la agricultura: comerciantes, servidores del Estado, artesanos, clero. En menos de un siglo, algunas ciudades habían visto Ilegar un corregidor (Logroño, Santo Domingo de la Calzada, Nájera), un inquisidor (Logroño, Calahorra), nuevas órdenes religiosas, pero también nuevos vecinos muchos de ellos extranjeros- que se dedicaban a actividades poco antes desconocidas: impresores, fabricantes de papel, constructores de "ingenios" que aprovechan la fuerza del agua para hacer molinos y batanes. Otras artesanías antes poco desarrolladas han crecido en trabajadores y se han dotado de nuevas técnicas: hay más bordadores, que hacen ricos ornamentos litúrgicos; escultores y arquitectos, muchos de ellos flamencos o franceses; plateros, que no sólo realizan bellísimas obras de arte, sino que aseguran el atesoramiento de la abundante plata, sacándola de los circuitos monetales. Y desde luego, ha aumentado extraordinariamente el número de los que se dedican a fabricar odres de cuero y "ollas" para almacenar el vino, así como el número de arrieros, de criados —incluso hay algunos esclavos negros en muchos pueblos - y de jornaleros, que cultivan las viñas. Estas han proliferado tanto, que han hecho cambiar el paisaje de los alrededores de algunas ciudades como Logroño, Haro o Nájera.

Las ciudades tienen más vecinos, pero también muchos más visitantes que antes. Ha aumentado el número de mesones para albergar a los tratantes serranos y a los campesinos que para vender o comprar visitan las ferias de Logroño, Nájera, Santo Domingo o Alfaro. Los mercaderes dan el tono de algunas ciudades. El comercio domina en el mundo ganadero de las sierras volcadas a exportar lana a Flandes. Todos, desde los grandes comerciantes hasta los campesinos, han empezado a manejar más frecuentemente el dinero y a sorprenderse de sus veleidades, del aumento constante de los precios y de su devaluación. En fin, grandes cambios en un mundo en el que todavía la quietud y la costụmbre eran los principales valores. En las páginas que siguen, los veremos oponerse al riesgo de la innovación.

\section{El Potencial Demográfico ante la Expansión}

En comparación con el resto de Castilla, incluso con sus comarcas más favorecidas, La Rioja es en siglo XVI una región superpoblada, como ha resaltado F. Brumont. Una densidad media cercana a los 30 habs./Km2, según datos elaborados 
a partir del censo de 1561, es una cifra considerable, sobre todo si se tiene en cuenta que aproximadamente un $40 \%$ de la región la ocupan las sierras, en donde la densidad era considerablemente menor, en torno a los 20 habs. $/ \mathrm{Km}^{2}$. Incluso en estas zonas de montaña, las densidades de población son superiores a las que Brumont observa en ricas comarcas cerealeras castellanas como la de Candemuño o La Bureba ${ }^{1}$.

Las zonas más densamente pobladas se sitúan en torno a las ciudades del Camino de Santiago - Logroño, Nájera y Santo Domingo de La Calzada-. El Camino Francés seguía siendo la vía tradicional para las relaciones económicas con la próspera Castilla, pero además, en La Rioja, las tres ciudades más importantes que lo jalonan son a su vez la puerta de los valles del Iregua, Najerilla y Oja, rutas naturales para la salida de la lana de las sierras y la exportación de productos agrícolas a los pueblos ganaderos, lo cual había reforzado su carácter de poderosos centros mercantiles. Alrededor de esas tres ciudades se agrupan pequeños pueblos, muy próximos unos de otros, que proporcionan altas densidades, superiores en muchos casos a los 100 habs./Km2. La raya del Ebro, que no despegará hasta el siglo XVIII, había sufrido más el impacto de las guerras y de la inestabilidad fronteriza - San Vicente de la Sonsierra es castellana desde 1463 - , lo que mantuvo poco poblados en el siglo XVI algunos núcleos como, por ejemplo, Cenicero o Fuenmayor. La complementariedad entre un valle de agricultura muy diversificada — con especialización en el viñedo en algunas comarcas - y una sierra volcada a la producción textil y de lana fina trashumante, fue una de las principales causas del crecimiento demográfico de esas comarcas de la Rioja Alta. Al contrario, La Rioja Baja, con una población tradicionalmente más concentrada - Calahorra, Cervera, Alfaro, Autol, Herceofrece menores densidades, al igual que ocurre con su sierra, en donde la producción lanera es menor ${ }^{2}$.

En conjunto, la región alcanzó en el siglo XVI un alto índice poblacional. Si creemos la cifra que arroja el censo de 1591 —según la elaboración de Brumont, 28.563 vecinos-, La Rioja no habría recuperado esa población hasta el siglo XIX. Logroño, que pasaría probablemente de los 10.000 habitantes en el mejor momento del siglo XVI, tenía poco más de 6.000 a mediados del siglo XVIII ${ }^{3}$.

El inicio de la inflexión es ya bastante conocido, como luego veremos; el problema es conocer los ritmos de crecimiento anteriores a la mitad del XVI, pues, como

1. Como hemos dicho, buena parte de los datos demográficos provienen de los trabajos de BRUMONT, F., especialmente 1986: y de los de LÁZARO RUIZ, M. y GURRÍA GARCÍA, P., especialmente, 1989. Una visión de síntesis, GÓMEZ URDÁÑEZ, J.L., 1994-95, concretamente los capítulos redactados por los autores citados. Para una bibliografía exhaustiva, vid. nota 3.

2. Las mejores visiones de conjunto, BRUMONT, F., 1986 y en 1994, especialmente los capítulos firmados por José Luis Gómez Urdáñez, Pedro L. Lorenzo Cadarso, Francis Brumont, Gregorio Torrealba y Santiago Ibáñez. Sobre la complementariedad, GÓMEZ URDÁÑEZ, J.L., 1983 y 1986.

3. BRUMONT, F., 1986 La última revisión del censo de 1591 realizada por S. Ibáñez da 28.831 vecinos, resultado de añadir dos pueblos que faltan en el censo. El censo de 1556 sitúa la población en 26.113 vecinos. El catastro de Ensenada da 28.831 vecinos. Los últimos datos me han sido facilitados por S. Ibáñez, resultado de su trabajo para la presentación en breve de su tesis doctoral. Sobre la población de Logroño, LÁZARO RUIZ, M. y GURRÍA GARCÍA, P., 1994 y ALONSO CASTROVIEJO, J.J. 1992. 
es sabido, no hay datos suficientes antes de la generalización de los registros parroquiales. Hay algunos casos de registros tempranos - San Miguel de Alfaro (1512), San Asensio (1502) - o de datos fragmentarios (Ausejo) o mal conservados (Cellorigo), pero, a juicio de M. Lázaro y P. Gurría, imposibles de utilizar. El único estudio, sobre datos fragmentarios, es el de J. Maiso y J.A. Salas sobre Huércan os ${ }^{4}$, en el que se aprecia un sensible aumento del índice de nacimientos entre 1506-17 (media de 13,6 por año) y 1551-60 (media de 17,5); lo que ratifica, contando siempre con la inseguridad de la cifras, la generalizada opinión del aumento de la natalidad en la primera mitad del siglo XVI. Con todo, en La Rioja, a esta tendencia general habría que sumar un fenómeno migratorio procedente del norte, todavía, si cabe, más difícil de cuantificar. Un fuerte flujo de emigración vasca y cántabra es comprobable en el siglo XVIII, gracias a fuentes excepcionales como son los libros de parroquianos de Logroño. Sospechamos que el apogeo del viñedo y su gran demanda de trabajo temporero, así como el incremento del comercio con el País Vasco basado en el vino y en la importación, vía puertos vascos, de productos europeos, fenómenos ambos que monetarizarán la economía riojana, son las causas de la atracción. Pero no hay que olvidar tampoco la propia dinámica económica vasca, su estructura familiar y su sistema de herencia, con tradicional tendencia a soltar población, aunque en "buenas condiciones", bien con experiencia en el arte de la cantería, la herrería, etc., bien dotados de títulos de hidalguía que pretendían reconocer en el lugar de destino. La generalización de la hidalguía - en algunas zonas, hidalguía universal - y el aprendizaje de oficios aseguraban una emigración en condiciones más ventajosas. Durante el siglo XVI podemos constatar el fenómeno a raíz del incremento constante de apellidos vascos que van apareciendo en la documentación de los diversos municipios del valle, sobre todo en los más próximos al Ebro, allí donde las densidades de población no eran tan fuertes todavía a mediados del siglo XVI ${ }^{5}$. Igualmente está comprobada la afluencia de canteros y artistas vascos, muchos de los cuales acaban fijando su residencia en alguno de los pueblos donde han realizado sus obras. La cronología de muchas de las iglesias y obras artísticas de envergadura, así como el urbanismo, es también un dato importante para constatar el temprano crecimiento de algunas comarcas y la decadencia de otras, como está comprobando Ana Mendióroz. Así, mientras que en algunas zonas, como en las de la raya del Ebro, habrá que esperar a la segunda mitad o finales del XVI para encontrar las grandes fábricas eclesiales, en las comarcas del sur del Camino, en torno a pequeños pueblos como Villamediana, Sotés, Daroca, las Arenzanas, Hornos de Moncalvillo, etc. se inicia ya desde mediados del XV la construcción de iglesias, típicas de ese primer esplendor castellano. No se suele reparar en la importancia que tiene el cambio de tendencia económica en la región - exportación lanera por el camino de Castilla en los siglos XV y XVI y auge de la saca del vino hacia el norte

4. SALAS AUSÉNS, J.A. y MAISO, J., 1976: 51-81.

5. Hasta el siglo XVIII no ha sido posible cuantificar la emigración vasca por insuficiencia en las fuentes, cfr. LÁZARO RUIZ, M; GURRÍA GARCÍA, P.A. y ORTEGA BERRUGUETE, A.R. 1988. 
en el XVII y el XVIII — a la hora de valorar los grandes monumentos artísticos. Pero, bastaría una mínima reflexión sobre la influencia de los procesos demográficos y económicos para apreciar una tendencia muy indicativa. Las grandes obras eclesiásticas de las proximidades del Camino, en las comarcas de comienzo de los valles que hemos indicado, son iglesias de gótico tardío, con portadas de fines del XV y ornatos y añadidos de la primera mitad del XVI; pero, luego, no hay grandes construcciones, como tampoco hay expansión urbana. Sin embargo, en las comarcas del norte, en torno a Briones, Cenicero, San Vicente de La Sonsierra, Laguardia sorprenden las grandes obras del romanismo y el barroco: iglesia empezada en el siglo XVI, retablo contratado a fines del siglo, pero dorado en el XVII -en consonancia con el inicio del inventario de ornamentos litúrgicos, que aún aumenta más en la centuria siguiente-, con remate de sacristía nueva y, sobre todo, con torre en el XVIII, de un estilo muy característico de la región como puede verse en las de Abalos, Briones, Logroño (La Redonda), Oyón o Murillo de río Leza 6 .

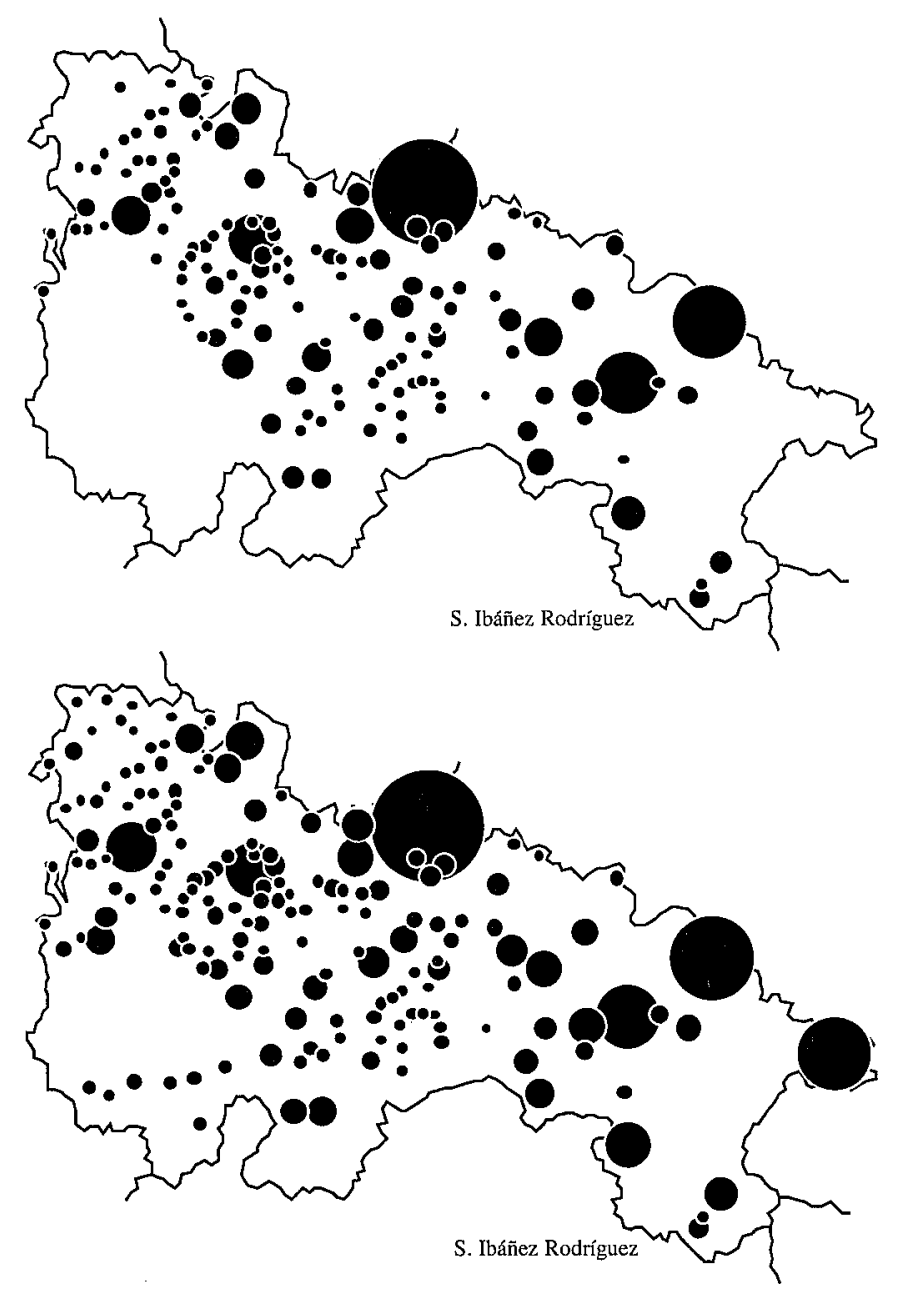

La población de La Rioja (según Ibáñez) en 1556 (datos conocidos) y 1591. Ambos mapas con la misma escala y círculos en progresión lineal. Los datos de las aldeas se han incluido en sus villas (Calahorra, Arnedo, Ocón, Ezcaray...)

6. CFR. MENDIÓROZ LACAMBRA, A. 1994. 
La detención del crecimiento demográfico no se produciría hasta la década de los setenta, igual que ocurre en la mayoría de las comarcas castellanas. Sólo algunos pueblos de La Rioja Baja y de la raya del Ebro — también con otras excepciones, como Pedroso y Anguiano en la sierra - seguirían creciendo hasta la gran peste de 1599; pero, en general, durante las dos últimas décadas del XVI se aprecia ya la detención del crecimiento. La peste de 1564-66 parece haber tenido poca intensidad y, en todo caso, una extensión geográfica no generalizada - aunque quizás esta apreciación sea producto de la escasez de fuentes-. Alfaro, Rincón de Soto o Calahorra, a pesar de estar en el camino de Zaragoza, foco tradicional de expansión de la epidemia, que provenía del sur de Francia, no se vieron afectadas. Por el contrario, la peste llegó a Logroño a fines del verano de 1564, y a puntos de la comarca de Nájera y a zonas más al sur, como Albelda y Torrecilla en el valle del Iregua, Anguiano en el del Najerilla o Ezcaray en el del Oja. Con todo, la evolución ascendente de la curva de bautismos no sufrió alteración hasta el año 1572. Desde 1571, una crisis de alto alcance — probablemente una crisis de subsistencias unida a un rebrote de tifus-, no constatada en Castilla, pero sí en Navarra, había iniciado la inflexión.

Hasta la gran peste finisecular, el movimiento descendente se generaliza, salvo pocas excepciones. Puntas de sobremortalidad en 1580 - el catarro-y en varios años de la última década del siglo hacen pensar en la conjunción de brotes epidémicos y crisis de subsistencias?. En suma, parece desprenderse de los trabajos de $\mathrm{M}$. Lázaro que la gran peste de 1599-1600 no es el origen de la recesión demográfica; antes ya se notaban los síntomas ${ }^{8}$.

A pesar de que La Rioja es un área marginal en la propagación de la gran epidemia — como se sabe, Aragón no la llegó a padecer—, la intensidad debió ser notable, aunque siempre menor que en la Castilla del norte. El célebre poema anónimo publicado por J. Simón Díaz valora en 6.000 los muertos en la ciudad de Logroño, cifra a todas luces exagerada, aunque indicadora de la gravedad del fenómeno. Cifras tan asombrosas son seguras para otras ciudades castellanas, como es conocido. La cercana Burgos, con una población algo mayor, sufriría entre 5.000 y 6.000 víctimas. En el resto de La Rioja, los datos conocidos dan intensidades menores, con algunas excepciones como Huércanos, donde pereció un 41,7\% de la población (372 personas). Calahorra con 300 muertos (7,5\%), Lagunilla con 98 (17,8\%), Cuzcurrita con $26(12 \%)$ o ya en la sierra Ajamil con un $8,1 \%$ y Muro con el $7 \%$, son ejemplos de una menor intensidad.

En cualquier caso, la epidemia termina con el esplendor del quinientos y anuncia el proceso de decadencia, también con aspectos diferenciales en La Rioja con respecto a Castilla. Como ocurriera con las crisis demográficas en el XVI, la crisis del XVII no fue tan severa como en Castilla, ni en la reducción de la población —aun-

7. En la ciudad de Logroño está constatada la aparición del hambre en 1561, 1576, 1578, 1582, 1583, 1586, 1588 y 1598; cfr., LORENZO CADARSO, P.L., 1988: 452.

8. Lázaro Ruiz, M., 1994. También en GÓMEZ URDÁÑEZ, J.L. 1994-95.

9. SIMÓN DÍAZ, J., 1952: 243-252. 
que la tendencia secular sea, en general, ligeramente negativa - ni en la crisis del sistema productivo. Factores como la relativa estabilidad del mercado vasco para la colocación del vino, que llegará a conocer una nueva y mayor expansión en Logroño y los pueblos del Ebro hasta Haro - y ahora ya sin la competencia de los caldos castellanos-, y el mantenimiento de la riqueza generada por la producción lanera y los centros urbanos mercantiles del Camino, contribuyeron a soportar mejor el siglo de la decadencia. Ello obligaría a cambios políticos y sociales de envergadura, que escapan al contenido de este trabajo ${ }^{10}$.

El alto índice poblacional de La Rioja es un factor que anuncia dinamismo social y expectativas en la estructura económica de la región. La propia diversidad productiva en las diferentes comarcas riojanas provocó siempre movimientos de población. La sierra siempre hubo de regular su crecimiento demográfico, expulsando efectivos humanos sobrantes en la explotación ganadera, tanto al valle riojano — sobre todo mano de obra estacional - como a los centros vitales de la ruta de la trashumancia ${ }^{11}$. Por ella, los serranos, necesariamente comerciantes en lanas, ganados y pastos, alcanzarían los puertos del sur y, desde ellos, saltarían a América, en donde continuarían su actividad comercial. A fines del XVIII, ya en la decadencia serrana, Soto seguía mandando paños a América, como antes lo habían hecho Ezcaray, Munilla o Enciso. Sin embargo, la primera emigración está marcada por las grandes expectativas y a ellas responden gentes de las comarcas más ricas y pobladas de La Rioja. En un estudio de M. Zuloaga, el 70\% de los emigrantes proceden de La Rioja Alta. Son capitanes, funcionarios, segundones de linaje en busca de fortuna y, sobre todo, clérigos, del mismo origen social generalmente. El conocido excedente de clero del obispado de Calahorra y algunas particularidades en el acceso a los beneficios parroquiales, que luego explicaremos, impulsó durante los dos primeros siglos de colonización una fuerte emigración de clérigos riojanos hacia ultramar, algunos con altos cargos eclesiásticos ${ }^{12}$.

\section{Los RECURSOS: COMPLEMENTAIREDAD Y DiVERSIFICACIÓN}

Diversidad agraria, especialización comarcal en torno a productos destinados al mercado - lana y vino_-, monetarización de los intercambios y redes interregionales e internacionales, son en la época Moderna los mejores indicadores de una economía

10. Puede consultarse al respecto LORENZO CADARSO, P.L., 1989:. 3-23.

11. Menos conocido el mundo de la trashumancia en La Rioja en los siglos XVI y XVII, puede comprobarse lo anterior para el XVIII, en GÓMEZ URDÁÑEZ, J.L., 1986: 105-140; MELÓN, M.A., 1986: 141-158; del mismo autor, 1989, con interesantes aportaciones sobre el papel de los emigrantes a Extremadura, especialmente a Cáceres, entre ellos algunos riojanos; en RUIZ RIBERA, J., 1988, una aportación sobre el número de comerciantes que se instalan en Cádiz, una buena proporción de procedentes de las sierras de La Rioja.

12. ZULOAGA RADA, M., 1985: 91-100; documentación cualitativa en LOPE TOLEDO, J.M., 195859. El exceso de clero y las peculiaridades parroquiales ya fue constatado por DOMÍNGUEZ ORTIZ, A., 1983: pp. 210-211. Un interesante trabajo inédito, LORENZO CADARSO, P.L., 1992. 
regional en expansión. La Rioja, a pesar de su escasa extensión geográfica, presenta cada uno de ellos de manera óptima.

La diversidad agraria, característica del fértil valle y de la sierra que lo limita al sur, que producen una primera base de riqueza por la complementariedad agro-ganadera, se manifestaba de forma más rotunda si cabe a causa de un reparto de la propiedad relativamente equilibrado, de una variada artesanía de transformación de productos agropecuarios y del necesario soporte mercantil que tienen en los núcleos urbanos del valle los productos destinados al mercado exterior, particularmente el vino y la lana. Así, no sólo la artesanía textil o vinícola propiciaban la transformación del paisaje agrario, incrementando viñedos en el valle - a costa de pastizales y eriales - y pastos en la sierra - a costa del bosque-; también se desarrollaron otras, aunque con menor impacto en el mercado, al amparo de cultivos como el lino y el cáñamo, la morera o el olivar. En Logroño se conocen ordenes del corregidor, en 1572-73, prohibiendo el hurto de hojas de morera en los términos de la ciudad "por cuanto en ella se cría mucha seda"13. Sabemos del aumento del cultivo del olivo y del número de trujales, sobre todo en La Rioja Baja, en dependencia de su exportación a la sierra, así como del lino y del cáñamo, que permitían mantener un tejedor en los pueblos grandes, aunque es conocido que estas plantas industriales, sobre todo el lino, se desarrollaron poco en España durante el siglo XVI. Las importaciones de productos elaborados del extranjero, así como las disposiciones dictadas en favor de su cultivo en tiempo de Felipe II, prueban, a falta de datos cuantitativos, el escaso desarrollo. Sin embargo, en el siglo XVI algunas comarcas riojanas, sobre todo en La Rioja Baja - Cornago y especialmente Cervera, así como Murillo de Río Leza, la tierra baja de Ocón y la tierra de Arnedo-, eran ya grandes productoras. A fines del $\mathrm{XVI}$, las quejas de los concejos de estas mismas zonas por el peligro de corrupción de las aguas a causa de las pozas o pudrideros del cáñamo, permiten apreciar que el cultivo estaba ya bastante desarrollado.

La variedad de usos del suelo y la estructura de la propiedad conferían al paisaje agrario una imagen muy distinta de la que se pudiera imaginar a raíz del tópico de una Rioja del viñedo y una sierra del ganado. De entrada, no se llegó a cultivar ni la mitad del suelo aún en las comarcas del valle más densamente pobladas. Todavía a mediados del siglo XVIII, cuando es segura la fuerte expansión de la tierra cultivada, ricas tierras como las de Cenicero, Logroño o Murillo de Río Leza, mantenían una proporción en torno al $50 \%$ o poco más; en zonas de media montaña, como los valles de Ocón y Jubera, el porcentaje no llegaba al 30\%. Igualmente, eran los menos los pueblos que dedicaban al viñedo más de la mitad del terrazgo cultivado. De todos los grandes centros productores destaca Logroño, en cuyo término dos tercios de la tierra cultivada eran viñas a finales del XVI. Algunos pueblos de la comarca najerina, el mismo término de la ciudad, y Navarrete y Fuenmayor, tenían también

13. Cfr., OCHAGAVÍA, D., 1957: 431. 
extensiones de viñedo superiores a las destinadas a pan y a huerta. Pero estos casos son excepcionales, como veremos.

En las comarcas del valle se mantenían grandes zonas de propiedad comunal destinadas a pasto de ganado de carne - en Logroño, por ejemplo, la llamada dehesa de Varea- y de tiro, así como muchos bosquecillos y sotos en las riberas, de los que se aprovechaba la leña y la caza. Aún en las comarcas de la raya del Ebro especializadas en el viñedo, se cultivaba en el regadío toda suerte de hortaliza de autoconsumo $y$, en las mejores tierras de secano, el cereal. Es el caso de pueblos tan volcados a la producción de vino como Cenicero o Haro. Una idea de la importancia de la huerta es que, durante la segunda mitad del siglo XVI, la producción de legumbres se triplicó, como demuestran los resultados obtenidos por S. Ibáñez en una serie suficiente de pueblos del valle. En La Rioja Baja, donde la propiedad comunal era mayor, amplias zonas estaban destinadas a pasto para la ganadería caballar, mucho más desarrollada que en La Rioja Alta, y para ganados trasterminantes. Los pastores de Enciso y Munilla bajaban sus rebaños, desde antes del siglo XVI, a los sotos de la franja próxima al Ebro entre Ausejo y Calahorra. En cualquier caso, en los grandes llanos de Alfaro, Calahorra o Aldeanueva predominaban las grandes extensiones cerealeras sobre cualquier otro cultivo.

En las estribaciones de la sierra, los baldíos "por naturaleza" aumentaban. La mayor superficie arbolada - Robles del Castillo estaba, en efecto, rodeado por robledal (hoy realmente inimaginable) - era aprovechada, además de para los usos comunes de la madera, para fabricar carbón vegetal. El valle del Cárdenas conoció gran desarrollo del carboneo por la demanda najerina, logroñesa y de Santo Domingo. Ya en las sierras, tradicionalmente ganaderas, el paisaje, en el que lógicamente predominaban los pastos de "verenadero", en buena parte de propiedad comunal, encontraremos también pequeños huertos dedicados a la hortaliza rodeando el caserío de los pueblos, y piezas dispersas dedicadas al cereal de autoconsumo humano y animal, así como extensos bosques que el sobrepastoreo no había podido todavía arrumbar. Salvo en las cotas más altas, la producción cerealera serrana, aunque no llegaba a la suficiencia, representaba un complemento importante. A falta de hombres, empleados en la trashumancia, el trabajo agrícola era desempeñado por las mujeres, mientras su producto representaba un seguro para el clero de las pequeñas aldeas vía diezmo. Por otra parte, el mayor abonado, las pequeñas superficies y un sobreequipamiento de animales de labranza, incrementaban los rendimientos, salvo cuando la presión demográfica o la elevación de los precios del grano provocaban el cultivo de tierras marginales de mala calidad ${ }^{14}$.

Una gran variedad de animales domésticos, colmenas para el aprovechamiento de miel y cera, pesca fluvial de numerosas especies — que permitía, en los pueblos del Ebro, mantener pescadores de red profesionales y que obligaba a un ayuntamiento

14. Los bajos rendimientos que ofrece F. Brumont se deben a alguna de éstas causas y a otras que él apunta; cfr., BRUMONT, F., 1986: 43. 
como el de Anguiano a regular en las ordenanzas de 1544 el precio de truchas, anguilas y barbos-, frutales dispersos en los lindes de las propiedades, árboles de sombra en los caminos y en los secanos, son algunos aspectos que ayudan a imaginar el paisaje transformado por una sociedad que aprovecha todo, desde la sanguijuela, con la que hará sangrías el barbero sangrador y cirujano, hasta los cueros, con los que el odrero fabricará los pellejos para el vino y el aceite, la lana basta de las ovejas churras, materia prima del tejedor de los pueblos del valle, o la leña que la crecida de los ríos ha dejado en las márgenes, en beneficio de los más pobres. En las localidades serranas, la recogida de los excrementos de los ganados por las calles para hacer estiércol era una actividad muy lucrativa, tanto que por realizarla algunos ayuntamientos cobraban una módica cantidad.

\section{La Especialización Agraria y la Ampliación de Mercados}

La diversidad y la autosuficiencia sólo es la base remota desde la que se proyecta el crecimiento económico del siglo XVI; éste, en La Rioja, se explica realmente por la tendencia hacia la especialización en dos productos - lana y vino-, muy monetarizadores al estar volcados al mercado, y por una vía comercial de fuerte tradición, que, auspiciada por el desarrollo del capitalismo mercantil, potenciará los grandes centros urbanos distribuidores.

Antes de nada, para no potenciar el tópico, convendrá decir que las comarcas que desde fines del siglo $\mathrm{XV}$ van a ver el desarrollo del viñedo son también grandes productoras de cereales, y conocen también, al unísono, el incremento de la producción cerealera, aunque éste es en algunas zonas relativamente menor. Según S. Ibáñez ${ }^{15}$, que ha estudiado los diezmos en quince localidades de La Rioja Media y Alta, la producción de vino pasó de 160.000 cántaras en 1537-41 a 360.000 en 1588-92; pero la de cereal también se incrementó: de 90.000 fanegas en la primera fecha a 144.000 en la segunda. En sólo 50 años, se producía un $122 \%$ más de vino, pero también un $60 \%$ más de cereal. Todo el valle riojano tenía una elevada producción triguera que el incremento del viñedo, salvo excepciones muy localizadas que luego veremos, no hizo disminuir, en términos generales, lo que nos hace pensar en la generalización de la puesta en cultivo de nuevas tierras (sobre todo, para destinarlas al viñedo en La Rioja Alta y al olivar, en la Rioja Baja). Cuando la expansión del viñedo no había llegado todavía a las cotas que alcanzará a fines de la centuria, la región ofrecía una prueba de prosperidad en el lugar que el trigo ocupa entre los cereales, representando en muchas zonas más del $50 \%$ del total.

15 IBÁÑ̃Z RODRÍGUEZ, S., 1991. 


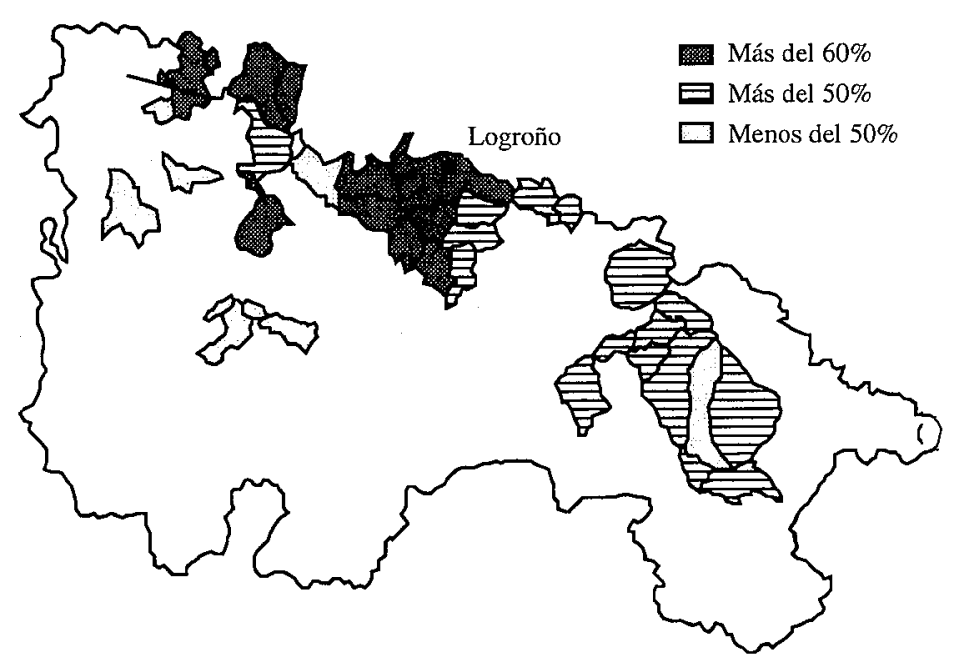

Porcentaje que representa el trigo frente al resto de los cereales en 1537-41. Datos de S. Ibánez.

En Cenicero se comprueba hacia mediados del XVI una gran transformación del terrazgo, con roturaciones masivas de pastos comunales, que llegan a plantear tensiones con los concejos limítrofes ${ }^{16}$. Aquí, como sucedió en toda La Rioja, incluso las laderas, las tierras pedregosas - con "guijo"- encontrarían en la vid el cultivo ideal. Pero, sólo unos pocos centros productores volcaron tierras de pan hacia el vino hasta llegar, en el apogeo, a provocar el déficit de cereales, como sucedió en Logroño, Navarrete, Fuenmayor y, quizás, en Nájera en algún momento hacia mediados de siglo. El déficit será soportable mientras se mantengan las buenas condiciones comerciales del XVI - las que precisamente han producido esa situación- y no provocará distorsiones hasta la nueva y más potente oleada expansiva de la vid de la siguiente centuria. Durante el siglo XVI, la zona de Logroño-Navarrete-Fuenmayor y la región najerina pudieron llegar al desequilibrio en favor del vino (que sólo Logroño mantendría hasta la época contemporánea) a causa de la potencia de sus centros comerciales y a costa de la producción cerealera de los pueblos próximos, de la que se abastecían: en Nájera, de la comarca de Sto. Domingo, y en Logroño, de sus aldeas y de la ribera navarra. De las 115.000 cántaras que producen Logroño y sus aldeas en 1545, el 75\% aproximadamente provienen del propio término de la ciudad, mientras que el total del trigo - unas 16.000 fanegas - se reparte casi por igual entre ciudad y aldeas, y el de avena y cebada, ya en un 60 y $70 \%$ a favor de las aldeas. Pueblos cercanos como Murillo de Río Leza, la tierra de Ausejo y los de la cuenca del Iregua aumentaron más la proporción de cereal -y, sobre todo, de la cebada - en favor del abastecimiento de la ciudad. Ausejo, en esos 50 años del XVI, duplicó la producción de trigo y aumentó la de cebada en dos veces y media, y en Lardero, una aldea de Logroño, el trigo aumentó un 8\% y la cebada hasta un 135\%. Los pueblos de la comarca logroñesa, al igual que los de la najerina, permitieron la

16. Vid., GÓMEZ URDÁÑEZ y otros, 1987: 197-201. 
especialización urbana en un producto marcadamente comercial, mientras ellos se ven forzados a suministrar sobre todo avena y cebada para consumo de los animales de tiro y transporte. Aunque las cifras de exportación de vino de Logroño que da Huetz de Lemps son realmente exageradas - unas 200.000 cántaras en 1580, una vez descontado el consumo interno-, hay que pensar en el número de mulas necesario para la saca anual del vino - y en la cebada necesaria para su alimentación, aunque sea sólo por un día-, a razón de ocho cántaras que podía transportar cada una ${ }^{17}$.

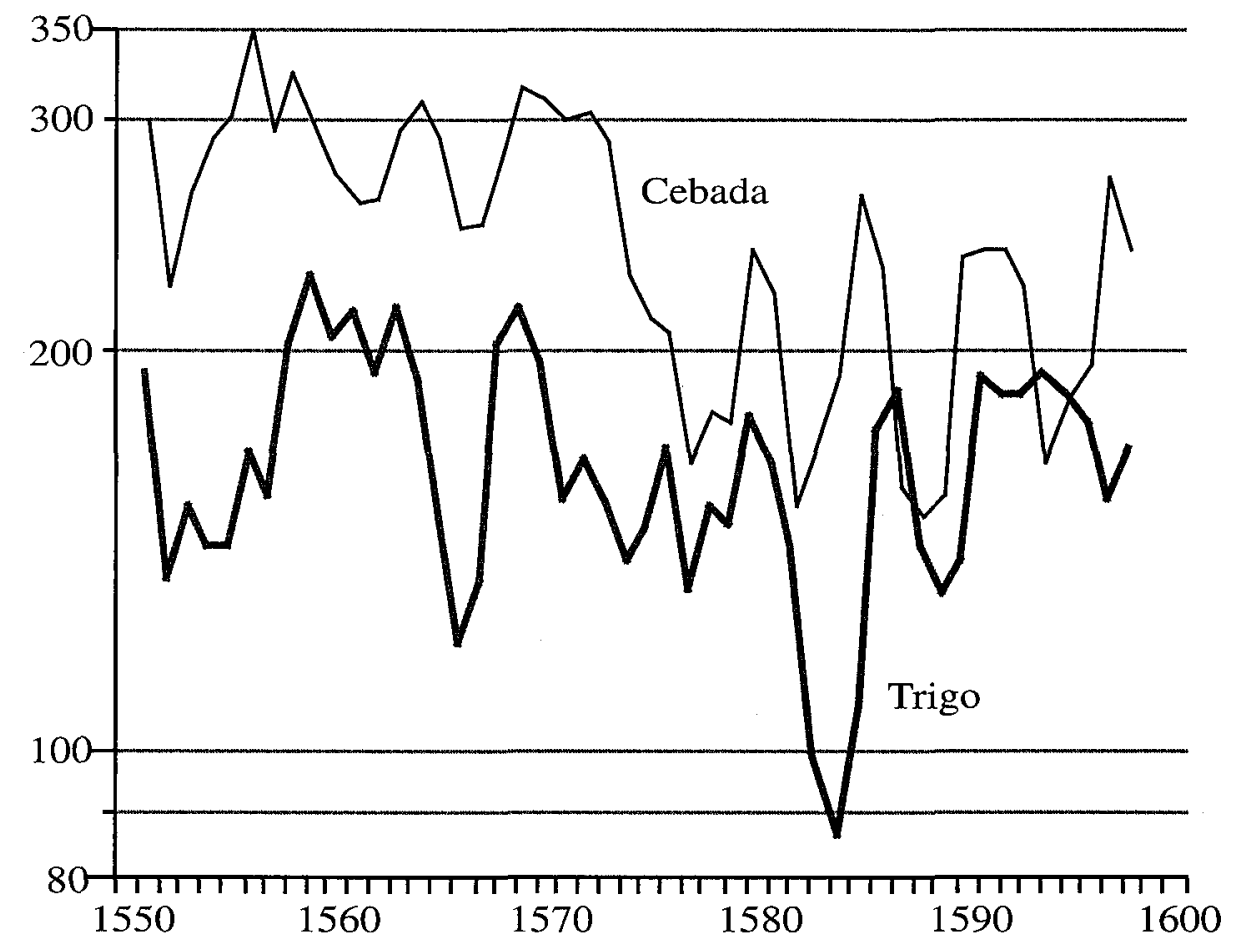

Producción de trigo y cebada en Fuenmayor (1550-1600)

El caso de Fuenmayor es muy indicativo. En 1560, según cálculos de S. Ibáñez, producía por vecino, 35 fanegas de cebada, 27 de trigo y 322 cántaras de vino. Se había producido ya una fuerte expansión del viñedo, pero los cereales seguían siendo rentables, más si cabe a causa de las sucesivas crisis de la década del sesenta. Los precios, en un relativo equilibrio, todavía frenaban la euforia vinatera; pero la tendencia se invirtió en la década siguiente, en cuanto los precios del vino comenzaron a subir más que los de los cereales. Se plantaron más viñas y descendió la cosecha de trigo; ahora, crecería la de centeno, el pan de pobres - entre 1560 y 1578 es el único cereal que aumenta (un 13\%) - y sólo se mantendría - y por encima del trigo-, aunque ya siempre a la baja, la de cebada, el alimento de las mulas. Así se llegaría a la década de los noventa, con un gran déficit alimentario, pero con los precios del vino constantemente en aumento hasta esta fecha. 
Medias móviles de 13 años de los número índice (base 100: 1555/59)

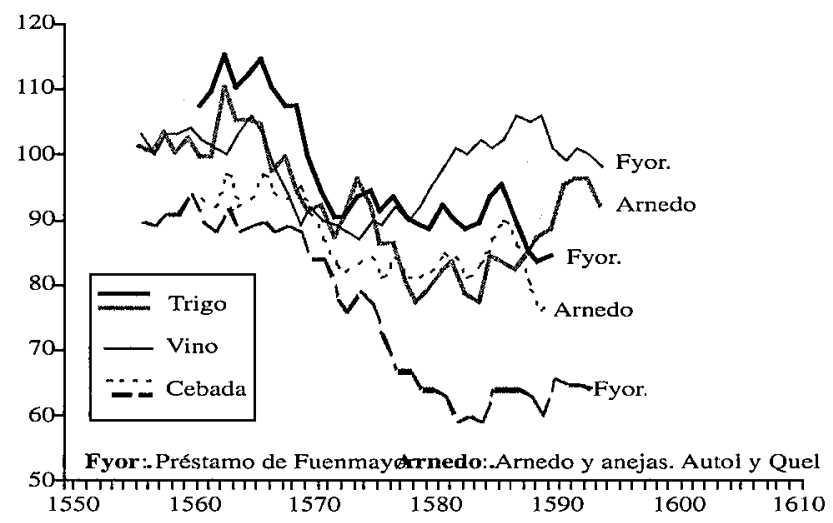

Evolución del trigo, la cebada y el vino en Fuenmayor en comparación con Arnedo (Rioja Baja).

Datos de Santiago Ibáñez.

En definitiva, el proceso de especialización vitivinícola en La Rioja Alta se produjo en la segunda mitad del siglo XVI, mientras, en el resto de la región se mantenían los productos clásicos, con más proporción del grano a medida que avanzamos hacia la parte oriental de la región. La comparación de los diezmos de algunas localidades no deja lugar a dudas ${ }^{18}$ :

Producción de los cereales básicos, vino y legumbres en La Rioja Según las averiguaciones de los subsidios de 1545 ( 1537/41) y 1595 (1588/92).

$\begin{array}{cccc}\text { Zona/Año. } & \text { Total grano } & \text { Vino } & \text { legumbre } \\ \text { Rioja Alta } & & & \\ 1545 & 785,5 & 1.381 & \\ 1595 & 1.037,6 & 7.696,2 & \\ \text { \% incremento } & +32,1 & +457,3 & \\ & & & \\ \text { Rioja Media } & & 9.831 & \\ 1545 & 3.772,3 & 19.083,1 & \\ 1595 & 3.817,1 & +94,1 & \\ \text { \% incremento } & +1,2 & & \\ & & 4.774,5 & \\ \text { Rioja Baja } & & 8.744,9 & \\ 1545 & 4.397 & +83,2 & \\ 1595 & 9.543 & & 310,9 \\ \text { \% incremento } & +117 & 15.986,5 & \\ & & 35.524,2 & \\ \text { TOTAL } & & +122,2 & \\ \text { 1545 } & 8.954,8 & & \end{array}$

18. Cfr. BRUMONT, F. e IBÁÑEZ RODRÍGUEZ, S., 1994: 147. Los datos proceden de S. Ibáñez. En loc. cit. los pueblos estudiados y las peculiaridades de las fuentes. Los datos expuestos en el cuadro sólo tienen un valor orientativo; sirven sobre todo para establecer la comparación entre las tres regiones. 


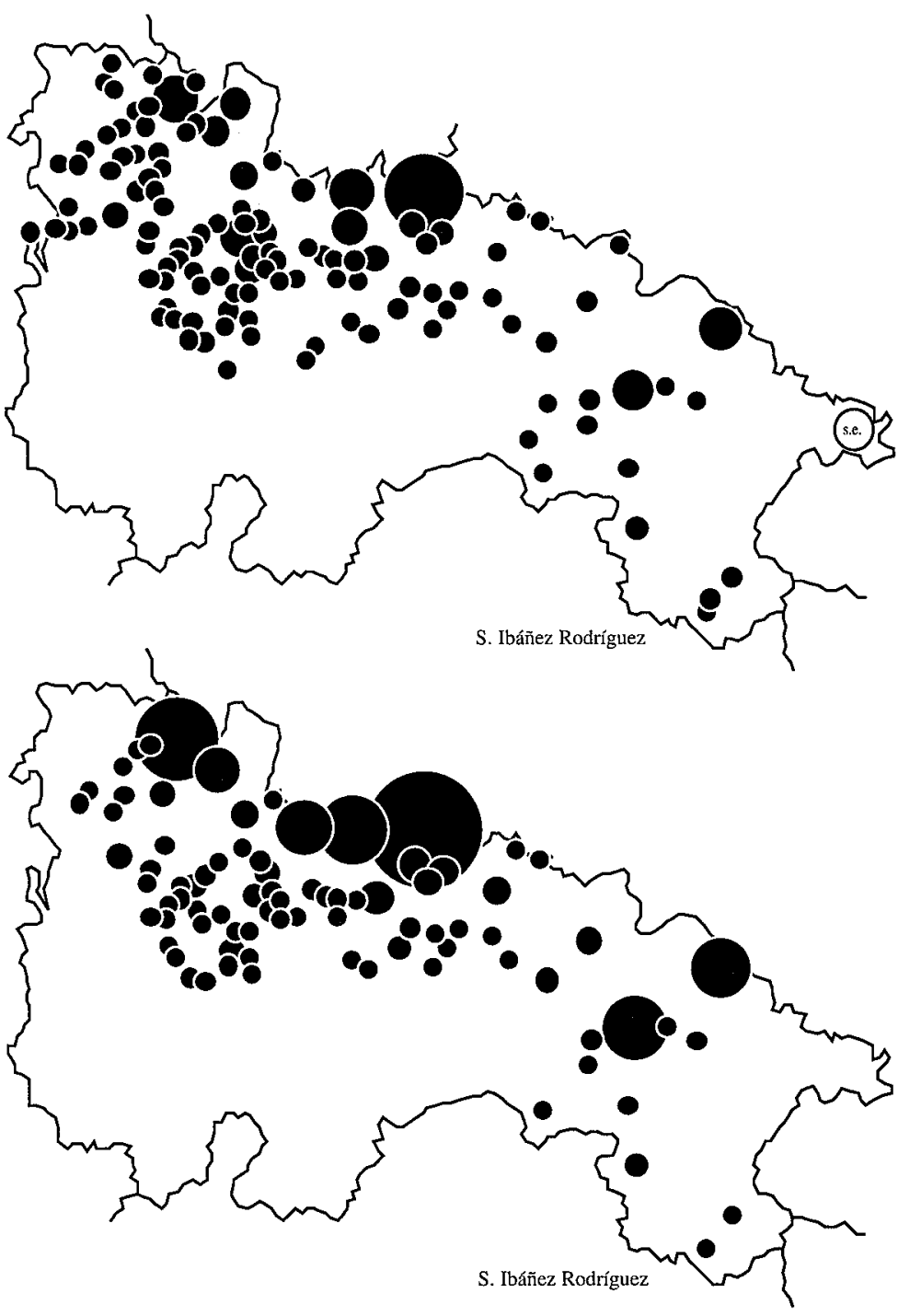

La producción del vino en La Rioja, arriba en 1537, abajo en 1591.(según Ibáñez)

Sólo la diversidad de mercancías que atraviesan La Rioja y los tratos interregionales e internacionales de gran número de mercaderes que acogen sus mayores ciudades son capaces de sostener un mercado para el vino que permita tal expansión ${ }^{19}$. Por eso, las coyunturas negativas, la contracción del comercio y la decadencia del mundo mercantil producirán drásticas caídas, con fuerte impacto social -hasta época contemporánea- y unas políticas locales muy especiales, en las que se confunden las oligarquías vinateras y sus objetivos con las instituciones y las necesidades generales. La mejor prueba es que el germen de la Sociedad Económica de

19. En 1560 , en cumplimiento de la nueva ordenanza real sobre exportación al extranjero de vinos, Alonso Ruiz, Francisco. de Sesma y Diego de Castejón, importantes mercaderes, formaron una sociedad mercantil para exportar vinó de Logroño a Brujas, actuando como agente en Flandes el dicho Diego Castejón. Es un buen ejemplo de la importancia que tenía para la producción vinícola el contar con una nutrida colonia mercantil en la ciudad. Archivo Histórico Provincial de Logroño (AHPLo.), Protocolos notariales de Bernardino. Rodríguez, Leg. 501, fol. 24. 
Amigos del País Riojano-Castellana es la Sociedad de Cosecheros de La Rioja, y que su gran obra es un camino a Santander para favorecer la saca del vino. Ya antes, desde mediados del siglo XVI, los grandes cosecheros habían logrado convertir el concejo logroñés, mediante perpetuaciones de regimientos y otras maniobras políticas, en una institución a su servicio. Habían llegado incluso a permitir el déficit crónico de cereales en las zonas más volcadas al viñedo, lo que durante las crisis agrarias lamentaban:

"Informa el coregidor que Logroño tiene una legua de jurisdicción, pero que su término dos tercios son viñas y uno heredades de pan llevar, y de eso no se labran la mitad por no haber labradores" ${ }^{\prime 20}$.

Pero, conscientes de los problemas que las hambrunas podía producir, cuidaron de los pósitos y de las panaderías - de propiedad del municipio- con gran interés. No era paternalismo, sino una manera de utilizar al máximo las redes comerciales, aprovechando el abaratamiento de costes que suponía el flete de retorno de los arrieros que sacaban la lana y el vino.

El otro producto que participa de la expansión económica de la región es la lana. Menos conocidas, a causa del abusivo predicamento vinatero regional, las explotaciones serranas dedicadas a la lana fina trashumante, fueron, desde al menos la segunda mitad del siglo XV, el factor fundamental de la expansión comercial de las ciudades del Camino, burgos mercantiles ya con varios siglos de tradición. Fueron, por esta razón, uno de los instrumentos básicos en la acumulación de capital mercantil. Probablemente, la misma expansión del viñedo en torno a estos ricos centros urbanos debe mucho al temprano tráfico de lanas y textiles, que inyectó capitales y consolidó rutas comerciales indispensables para la exportación del vino. Compárese en el siguiente cuadro la actividad exportadora de ciudades agrícolas como Logroño o Nájera con localidades serranas ganaderas. Logroño, el caso extremo, no tenía más que una ganadería mínima para abasto de sus carnicerías, que, además, no era de cria; la ciudad compraba carneros en Yanguas, Agreda, Soria, Castrojeriz, y los dejaba pastar en la dehesa comunal de Varea hasta que eran sacrificados. La oligarquía vinatera se había cuidado de impedir incluso el pequeño rebaño complementario de los pequeños propietarios, mediante prohibiciones de pastar en las viñas, que ocupaban la mayor proporción del terrazgo. Sin embargo, los mercaderes de Logroño aparecen como grandes exportadores de lana, a la altura de los de Torrecilla o Ezcaray ${ }^{21}$, lo que no le pasó desapercibido a Enrique Cook, a pesar de que cuando pasó por Logroño, en 1592, el comercio logroñés de exportación de lana había decaído ${ }^{22}$.

20. VIÑAS Y MEY, C., 1941: 217. Hay multitud de informes sobre la abundancia de viñas y la falta de "panes". Cfr. AGS, C.R.C., Leg. 454, 11, para el año 1577.

21. CFR. BRUMONT, F. E IBÁÑEZ, S., 1994: 141 y ss. Una visión general en LAPEYRE, H., 1981 y en BASAS FERNÁNDEZ, M., 1963.

22. El viajero y notario apostólico que acompañó a Felipe II habla de la riqueza de la comarca, de los vinos - que no le gustaron a excepción de los claretes-, de la abundancia de regadío y frutales y, al referirse a Logroño, del "gran trato de lanas que se saca". Cfr. GARCÍA MERCADAL, 1952: t. I, 1.293 y ss. 
LA RIOJA A COMIENZOS DE LA EDAD MODERNA

Exportaciones de lana (sacas de 8,5 arrobas) (según Brumont)

$\begin{array}{lcccccc}\text { Villa } & \mathbf{1 5 6 0} & \mathbf{1 5 6 1} & \mathbf{1 5 6 2} & \mathbf{1 5 6 3} & \mathbf{1 5 6 4} & \mathbf{1 5 6 5} \\ \text { Logroño } & \mathbf{7 9 5} & 659 & 530 & 694 & 250 & 1.095 \\ \text { Sto Domingo } & - & 441 & 352 & 476 & 133 & 706 \\ \text { Torrecilla } & - & 332 & 140 & 442 & 123 & 1.468 \\ \text { Ezcaray } & - & 0 & 314 & 0 & 96 & 161 \\ \text { Nájera } & - & 131 & 401 & 185 & 389 & 810 \\ \text { Viguera } & - & 0 & 0 & 0 & 0 & 237 \\ \text { Navarrete } & - & 0 & 0 & 0 & 0 & 170 \\ \text { RIOJA } & - & 1.563 & 1.737 & 1.797 & 991 & 4.647 \\ \text { Burgos } & - & 9.682 & 7.859 & 3.736 & 3.619 & 3.368 \\ \text { Segovia } & - & 2.559 & 4.184 & 2.620 & 2.690 & 5.054 \\ & & & & & & \\ & \mathbf{1 5 6 6} & \mathbf{1 5 6 7} & \mathbf{1 5 6 9} & \mathbf{1 5 7 0} & \mathbf{1 5 7 1} & \mathbf{M e d i a s} \\ \text { Logroño } & 543 & 776 & 112 & 830 & 668 & 616 \\ \text { Sto Domingo } & 52 & 797 & 5 & 252 & 254 & 347 \\ \text { Torrecilla } & 1.325 & 946 & 96 & 812 & 649 & 633 \\ \text { Ezcaray } & 156 & 171 & 0 & 73 & 152 & 112 \\ \text { Nájera } & 443 & 2.220 & 363 & 624 & 1758 & 732 \\ \text { Viguera } & 29 & 399 & 0 & 0 & 38 & 70 \\ \text { Navarrete } & 80 & 0 & 0 & 0 & 31 & 28 \\ \text { Alfaro } & 0 & 0 & 38 & 4 & & \\ \text { RIOJA } & 2.628 & 5.309 & 576 & 2.621 & 3.588 & 2.542 \\ \text { Burgos } & 5.553 & 8.736 & 1.191 & 10.537 & 7.125 & 5.184 \\ \text { Segovia } & 2.212 & 4.790 & 65 & 7.285 & 3.301 & 3.476 \\ & & & & & & \end{array}$

Los orígenes de los grandes mercaderes que a mediados del siglo XVI encontramos establecidos en Logroño o Nájera hay que buscarlos, como veremos después, en pueblos de la sierra y en el trato directo de lanas y paños. Una vez establecidos en las ciudades, amplían y diversifican su actividad comercial —incluyendo los lucrativos negocios del contrabando fronterizo y de los préstamos a corto plazo--, convirtiéndose en intermediarios entre los fabricantes-comerciantes serranos, colocando sus paños, por medio de sus factores, en Medina de Rioseco, Burgos, Bilbao, Galicia, Asturias y el extranjero. Son muchos los comerciantes individuales y las compañías de riojanos y cameranos que exportan lanas a Brujas, Nantes, Ruan y otras ciudades del norte ${ }^{23}$.

La concesión de créditos y la distribución de los caros productos para teñir - pastel francés, añil y productos americanos- complementan sus negocios en relación con los pañeros de la sierra. Con todo, los grandes centros productores de la sierra

23. Una de las compañías de exportación de lana a Flandes dejó su "marca" en el protocolo de constitución; desgraciadamente ha sido divulgada como marca del vino de Rioja, como ya señalamos en GÓMEZ URDÁÑEZ, J.L., 1994-95: vol. III 479. El documento con el anagrama en AHPLo. Protocolos, leg. 501, f. 4. 
siguieron albergando una nutrida red de comerciantes, desde los propios grandes ganaderos que a la vez son fabricantes -empleando mano de obra asalariada o practicando ya un claro verlagsystem - y aprovechan la ruta de la trashumancia para colocar sus productos en las ciudades andaluzas y en América, hasta los que, en los grandes centros productores - Villoslada, Torrecilla, Soto y Ezcaray-, han abandonado sus actividades artesanales o ganaderas y, ya ricos y, seguramente, con poder político, para dedicarse únicamente a comerciar. Las familias Valladolid, de Ezcaray, o De la Rivera, de Torrecilla, son dos ejemplos ilustrativos para la segunda mitad del siglo $\mathrm{XVI}^{24}$.

La base de esta fuerte actividad mercantil es la alta concentración de ganadería lanar en las sierras, en proporción creciente, de manera general, en relación directa con la altitud. En esa misma proporción se irá produciendo la superioridad de la ganadería trashumante sobre la estante. El valle y los pueblos de altitudes medias tenían también una fuerte presión de la ganadería ovina estante, especialmente en cuanto nos adentramos al Este del Leza, en La Rioja Baja. Su utilidad era, sin embargo, menor: criaban ovejas para carne y queso - por la demanda de las ciudades próximas-, y lana de baja calidad para el consumo interno - sayales, xergas, mantas y colchones-, otras veces mezclada o procedente de cruces de las churras con machos merinos, para poder conseguir la lana entrefina, que aún tenía posibilidades de ser exportada. Con todo, destacan concentraciones como las que, hacia 1580, se producen en Murillo de Río Leza o Autol (unas 10.000 ovejas), Ausejo (8.700) o Calahorra (20.000), cantidades que sobrepasan a las que observamos en algunos pueblos cameranos; aunque, probablemente, parte del ganado pertenecía a pastores de los pueblos serranos próximos, que utilizaban los comunales de las riberas, como hemos visto en Enciso-Munilla e incluso en Soto y el valle del Jubera, en donde se practicó la trasterminancia entre el valle del Leza y del Cidacos y el del Ebro desde Logroño hasta Ausejo y Pradejón.

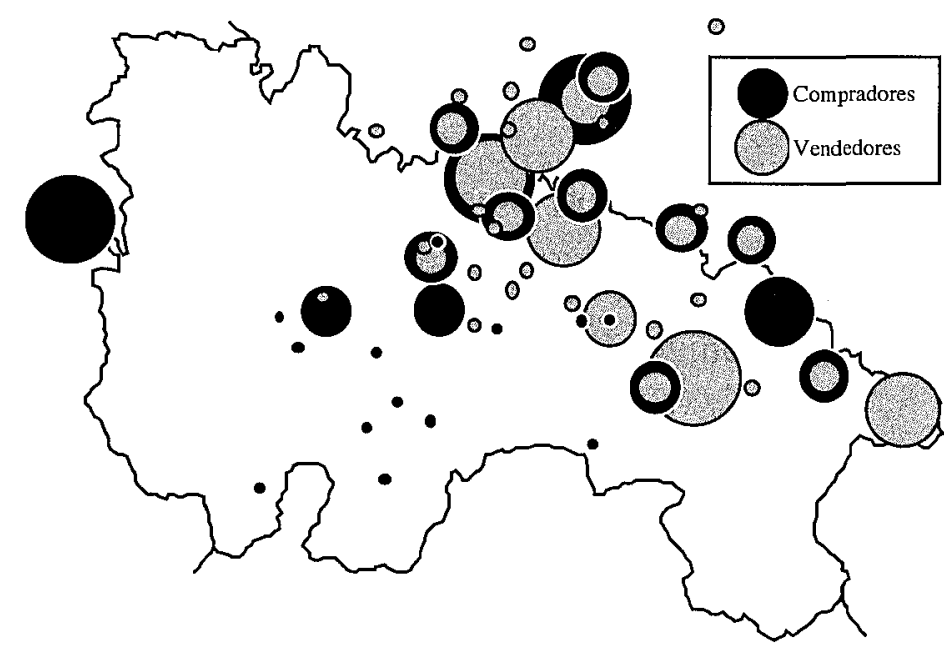

El mercado logroñés de la lana churra (según Brumont)

24. Cfr., BRUMONT, F., 1986: 56 y ss. 
Las altas densidades de oveja trashumante se concentran en el alto valle del Najerilla, en pueblos como Brieva (21.000 cabezas), Anguiano (cerca de 10.000) o Viniegra de Abajo y Mansilla (13.500). También en estos lugares encontramos los mayores rebaños, en 1586 hay propietarios con 8.000 cabezas (Mansilla), con 5.500 (Viniegra de Abajo) o con 5.000 (Brieva). Por su parte, la sierra de Cameros parece haber conocido una menor concentración, aunque pueblos como Ortigosa tienen propietarios todavía mayores. Precisamente los ganaderos de esta villa ocuparán el segundo puesto, tras los segovianos, entre los mayores arrendadores de dehesas en Cáceres ${ }^{25}$. Sin duda que en Cameros, el mayor número de pueblos y de aldeas, la mayor densidad de población y un mayor número de pequeños propietarios - lo que tampoco excluye casos de propiedad concentrada como Ortigosa, Villoslada y Torrecilla-, así como la existencia de un mayor número de vecinos que no poseen ganado trashumante por su dedicación a la agricultura y, en los pueblos más bajos de 1a comarca, al jornalerismo estacional, podría explicar el menor volumen de su cabaña ganadera. Así F. Brumont da para seis pueblos del Alto Najerilla una media de 83,5 ovejas por vecino, que se reducen a 32 en Cameros. Sin embargo, cuando se cuantifica el ganado de los grandes pueblos incluyendo el de sus numerosas aldeas - extremo no siempre aclarado en la documentación y de ahí las contradicciones-, las cifras resultantes son tan altas en el Alto Camero Nuevo como en el Alto Najerilla. Con sus aldeas, Lumbreras llegaría a tener, en el XVII, 90.000 cabezas, Ortigosa 70.000 , el entorno de Laguna otras tantas y Villoslada más de $100.000^{26}$. También hay que tener en cuenta que estas mayores densidades sólo se produjeran en el punto máximo de la expansión y de la concentración de la propiedad, y que todavía en el XVI la cabaña camerana no estuviera tan desarrollada; al menos es seguro que se componía de rebaños más pequeños, propiedad de vecinos dedicados también a otras ocupaciones - la agricultura, el textil y el jornalerismo estacional—, que se juntaban o se unían a los de los grandes propietarios para trashumar.

La diversidad ocupacional - con un fuerte sector orientado exclusivamente al mercado - y la alta monetarización de la economía serrana fueron siempre una constante que el creciente capitalismo mercantil del XVI no haría sino incrementar. El siglo de la expansión vería actuar nuevos mecanismos económicos que iban transformando paulatinamente las estructuras sociales y económicas. Así, es evidente una creciente proletarización, tanto en el sector ganadero como en el textil. A medida que aumentaban los rebaños de los grandes propietarios, se reforzaba la figura del comerciante de lanas y paños y se iba dañando el ciclo doméstico del pequeño propietario, cuya familia fabrica unos pocos paños que el marido "lleva a extremo para pagar la yerba y coste de su ganado". Pueblos como Matute tienen ya a mediados del XVI

25. PEREIRA, J.L., 1983: 127-139; BRUMONT, F., 1986: 48; y OCHAGAVÍA, D., 1957, con varios documentos transcritos al respecto.

26. Cfr., OCHAGAVÍA, D., 1957: 4. 
de veinte a veinticinco oficiales "que andan alquilados a jornal en casa destos tratantes, por no tener caudales con que hacer ni labrar paños"27.

\section{UNA SOCIEDAD MUY DINÁMICA}

La Rioja en su conjunto, pero muy especialmente La Rioja Alta y Cameros, presentaban a finales de siglo XV una organización social altamente dinámica, reflejo de una economía destinada con decisión hacia la comercialización y resultado de una evolución histórica en la que el Camino de Santiago y el carácter fronterizo de la región propició la temprana aparición de burgos mercantiles y artesanales.

El dinamismo social se fundamenta también en la ausencia de élites nobiliarias urbanas poderosas - a pesar de la fuerte señorialización de la región-, lo que favoreció la movilidad social y retrasó la formación de oligarquías concejiles de base nobiliaria hasta bien entrado el siglo XVI y, en la mayoría de los casos, hasta el siglo XVII.

Entre el campesinado eran raras las grandes fortunas; incluso en pleno siglo XVIII, cuando se realiza el Catastro, la mayor parte de la tierra está en manos de pequeños y medianos propietarios: no hay latifundios. Cabe diferenciar tres grandes zonas en la región. En La Rioja Baja predominan los pequeños propietarios dedicados a la producción cerealística, muy dependientes de las amplias extensiones de terrenos comunales en las que criaban yeguas, mulos, caballos y, como hemos visto, una gran cantidad de ovino estante, con un excelente mercado en La Rioja Alta, que necesitaba importar la práctica totalidad del ganado dada su carencia de pastos comunales y las crecientes exigencias de mulos para el acarreo del vino. El cereal encontraba el mismo mercado, al que hay que sumar el de las cercanas sierras de Cameros. Todavía en el siglo XVII, cuando hay que suponer que se ha producido una considerable concentración de la propiedad, las ventas de trigo - según la documentación del Pósito de Logroño ${ }^{28}$ - las hacían una multitud de pequeños propietarios, que complementaban con su excedente de cereal y la cría caballar sus ingresos familiares. Pese a todo esto, La Rioja Baja será una zona periferizada en relación con los avances de la agricultura comercial del XVI; tendrá, por ello, menor densidad de población y una economía menos dinámica.

La Rioja Alta vivió desde finales del siglo $X V$ una auténtica revolución de sus estructuras agrarias y comerciales. La causa, como hemos visto, es el vino, que tuvo una continuada expansión desde mediados del siglo XV, sobre todo entre 1490-1504 y a partir de $1535-1545^{29}$. La expansión vinícola trajo consigo profundos cambios en la sociedad campesina. Se dañó la complementariedad agroganadera, que resultaba incompatible con la gran expansión de la viña, lo que condujo a desequilibrar la di-

27. BRUMONT, F., 1986: 58-59.

28. Cfr., TORREALBA DOMÍNGUEZ, J.G., 1989.

29. Cfr., BRUMONT, F., 1984: 17. 
versidad que sostenía la extendida economía de autoconsumo: la economía se monetarizó y hasta los pequeños propietarios se vieron forzados a destinar más tierras a la viña, así que tuvieron que utilizar más el mercado. Los mercados francos un día a la semana, así como las ferias - una o dos anuales-, basadas en privilegios otorgados desde la repoblación —-por ejemplo, Logroño, desde el fuero de 1095-, tuvieron también mucha importancia en el comercio interior.

Los pequeños propietarios no hacían sino seguir las pautas que marcaban los grandes hacendados, quienes realmente se habían volcado al viñedo, propiciando un aumento del jornalerismo, alimentado por los salarios altos - sobre todo los de ciertos trabajos especializados como la poda- y la gran demanda de mano de obra durante la cava y la vendimia ${ }^{30}$. Logroño podía tener a mediados del siglo hasta un $40 \%$ de vecinos sin tierra, mientras incluso las clases no campesinas - escribanos, médicos, mercaderes, artesanos - adquirían viñas, que daban a cultivar a jornal. Casi no tenían otra propiedad que viñas: de nueve inventarios estudiados por Brumont, se desprenden proporciones del 100\% o cercanas: un platero tiene 3,2 ha., un gran mercader de la familia de los Yanguas, 15 ha.; todo son viñas. Otro rico mercader, también de la familia Yanguas tiene 31 ha., de las que el $98 \%$ es viña ${ }^{31}$. Los pequeños propietarios, que cultivan por sí mismos sus tierras, no llegaban a estas proporciones, por una mínima prudencia, pero los precios del vino en crecimiento y las características del cultivo - todas las labores a mano y con azada, sin necesidad de ganado de fuerza - les hacía ver que el viñedo les permitía obtener más rentabilidad que el cereal y acabaron cediendo a la tentación.

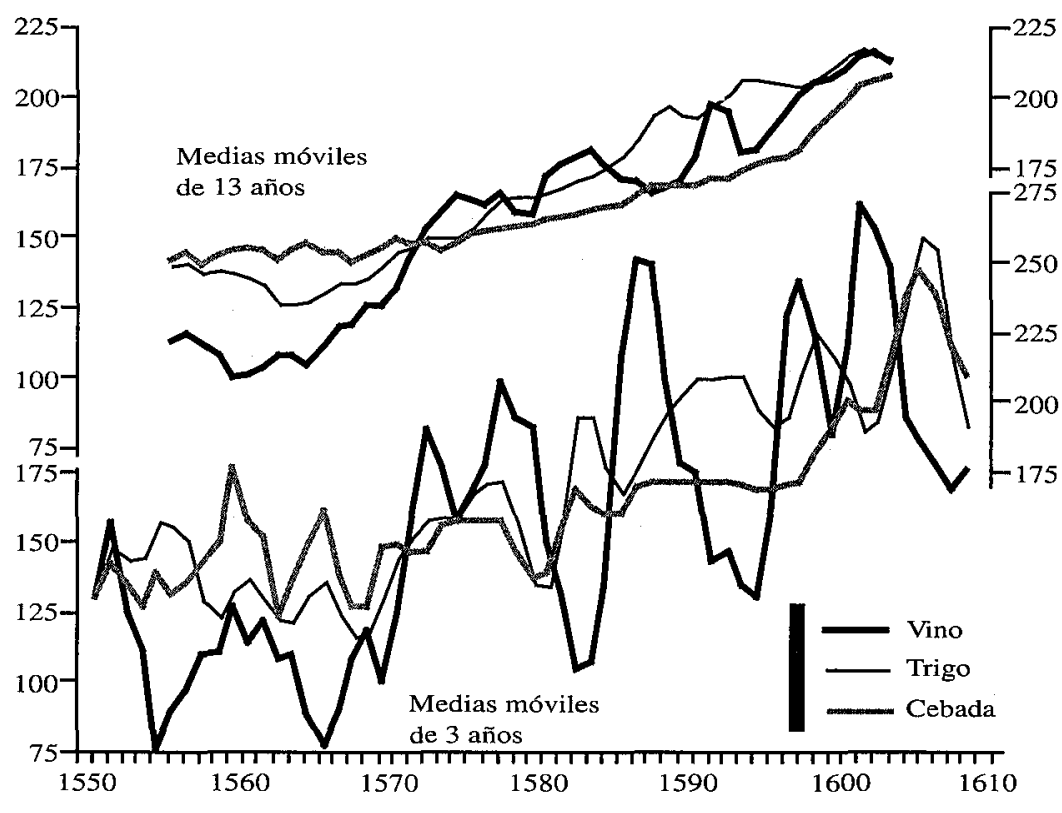

Evolución de algunos precios durante el siglo $X V I^{32}$

30. Cfr., LORENZO CADARSO, P.L., 1989: 81-96.

31. BRUMONT, F. e IBÁÑEZ, S., 1994:. 131.

32. El gráfico en GÓMEZ URDÁÑ̃EZ, J.L. 1994-95: vol III, 152. 
El resultado es que, periódicamente, el circuito de exportación o la propia producción entraban en crisis, y los precios presentaban fuertes caídas, obligando a una drástica disminución de salarios —impuesta incluso desde los concejos- y dejando ver la falta de trigo, que las oligarquías habían de comprar a toda costa para impedir el conflicto social ${ }^{33}$. Por eso Cook reparó en la gran alhóndiga de trigo de Logroño "donde se provee para mucho tiempo para la necesidad que se puede ofrecer"34.

El sector ganadero serrano sufrió aún más la evolución capitalista de la centuria. Las redes financieras que controlaban el mercado de lanas, fuertemente volcado al exterior por los consulados de Burgos y Bilbao, presionan en favor de la concentración de la propiedad ganadera. Los pequeños propietarios, que complementaban sus ingresos procedentes de la venta de lana en bruto con la elaboración doméstica de paños bastos, fueron encontrando crecientes dificultades en un mercado cada vez más especulativo y muy sensible a la coyuntura nacional e internacional. El resultado en las sierras es una marcada diferenciación social, que conducirá a los ricos hacia el mundo de los negocios laneros, mientras se crea una amplia capa social de criados, jornaleros, oficiales del textil asalariados, con fuerte tendencia a la emigración temporal. Pero, una economía tan dinámica permitió la subsistencia de un buen número de pequeños propietarios que resisten a base de diversificar su ocupación: serán trajineros entre valle y sierra — suben vino, aceite y pan, bajan carbón, yeso, algún paño, etc.-; cultivan pequeñas parcelas — generalmente con mano de obra femenina-, en las adversas coyunturas ganando tierras marginales, bancales, fuertes laderas, a fuerza de un enorme trabajo humano; se ajustarán, finalmente, con amos del valle en las épocas de más trabajo agrícola, mientras hasta los hijos de corta edad sirven en la zagalería trashumante. Una sociedad tan polarizada manifestó, sin embargo, una calma social y política extraña en comparación con la del resto de la región. Fueron raros los conflictos antiseñoriales y las movilizaciones populares, tan frecuentes en el valle.

Pero el grupo social que dará el tono a la sociedad riojana de finales del XV y durante todo el XVI serán los mercaderes. Gentes de extracción social diversa, normalmente baja - muy pocos son hidalgos-, algunos forman parte de linajes judíos convertidos al cristianismo recientemente, otros son extranjeros, franceses (José de Ibayzábal), ingleses (Mateo de Arbieto) o flamencos, pero la mayoría proceden de los principales centros de producción y comercialización de la lana serrana - Soto, Torrecilla, Yanguas, Ezcaray - o de los centros mercantiles vascos que enlazaban a la economía castellana con Europa - Bilbao, Vitoria, San Sebastián-. Su origen geográfico no solía coincidir con su lugar de residencia; normalmente empezaban en el mundo de los negocios actuando como agentes comerciales de otros mercaderes más poderosos y, cuando acumulaban cierta fortuna, abandonaban su lugar de origen

33. Las consecuencias de las crisis periódicas se dejan notar en la evolución de los pósitos, que están siendo estudiados por G. Torrealba en su tesis doctoral. Sobre los conflictos, cfr. LORENZO CADARSO, P.L., 1989.

34. En GARCÍA MERCADAL, 1952. 
para trasladarse a los principales centros mercantiles del valle - Logroño y Nájerao incluso a las plazas castellanas - Burgos, Medina del Campo, Toledo o Sevillay extranjeras - Londres, Brujas, Amberes, etc.-.

Hasta bien entrado el siglo XVI los mercaderes constituyeron sólidas y poderosas comunidades en las principales villas y ciudades riojanas, en las que formaban parte de la élite local sin discusión alguna. En Logroño controlarán el concejo de una manera casi ininterrumpida hasta 1560 y formaron poderosas compañías de comercio internacional. Los Sesma, los Soto, los Moreno, los González Rejón, los León y otros muchos utilizaron Logroño como centro de operaciones, aprovechando sus privilegios fiscales y su excelente radicación geográfica, pero normalmente vivían fuera de la ciudad, en Medina, Burgos o Flandes - Francisco. de Sesma, por ejemplo, dejó un hijo natural en Amberes- ${ }^{35}$.

Las comunidades mercantiles de los pueblos serranos están más dispersas geográficamente, aunque algunos núcleos destacan sobre los demás dentro de cada valle. En el del Oja-Tirón será Ezcaray el principal centro, en el del Iregua Torrecilla, aunque también Viguera contará con importantes mercaderes; en el del Leza será Soto de Cameros; en el del Cidacos, durante el siglo XVI, el principal será Yanguas, seguido de lejos por Enciso. Las colonias de mercaderes de la La Rioja Alta serán especialmente dependientes del comercio textil y lanero serrano. Nájera es un buen ejemplo de esta dependencia, siendo su mercado local un importante centro de redistribución al que acudirán mercaderes de toda Castilla. Los mercaderes de Logroño, por el contrario, tuvieron mucho más diversificados sus negocios. Hasta el último tercio del siglo XVI las grandes fortunas mercantiles de la ciudad las harán los mercaderes metidos al comercio de la lana camerana. En 1578, el duodécimo principal mercader lanero de Castilla en exportaciones por el Cantábrico era Juan Ribera Plaza, vecino de Logroño, que pagó $344.430 \mathrm{mrs}$. de derechos aduaneros. Entre 1561 y 1571, 23 mercaderes laneros logroñeses pagaron derechos aduaneros por un total de 3,203.791 mrs., lo que coloca a Logroño entre las principales ciudades castellanas dedicadas al mercado lanero. Pero, desde estas mismas fechas, cuando la recesión de la demanda flamenca comenzaba a manifestarse, los mercaderes de Logroño empezaron a diversificar sus negocios, valiéndose de los contactos que ya tenían en las principales ciudades castellanas, vascas y extranjeras: fundaron compañías destinadas a la exportación de vino a Flandes -Alonso Ruiz y Diego de Sesma, $2^{\circ}$ y $3^{\circ}$ mercaderes laneros en volumen de negocios en 1566-1571- (una vía que, dicho sea de paso, no debió de dar muy buenos resultados); y, sobre todo, aprovechando la solvencia financiera de Castilla y el diferencial de inflación, centraron sus actividades en los negocios de importación, pagando en metálico con la reputada moneda castellana de plata. En 1591, de los 51 mercaderes al por mayor que hay en la ciudad, 43 alternan el comercio textil con la importación de especias y 10 se dedican exclusiva-

35. Cfr. GÓMEZ URDÁÑEZ, J.L. 1994-95: vol. III, Los rangos sociales y especialmente, CARRETERO ZAMORA, J.M. 1994. 
mente a la importación de hierro y pescado de origen vasco ${ }^{36}$. La tendencia se generalizaría posteriormente y, a comienzos del siglo XVII, son ya pocos los mercaderes que participan en el mercado lanero de exportación, incluso los dedicados a productos textiles elaborados disminuirían drásticamente.

La lana camerana supuso el primer impulso al desarrollo mercantil y financiero de la región, pero la importancia de los mercaderes no terminó ahí, sino que fueron fundamentales para consolidar el desarrollo de todos los sectores agrarios destinados a la comercialización. La producción vinícola se desarrolló precisamente en las localidades que más directamente participaron del comercio de importación: los mismos trajineros que traían los productos vascos y europeos a centros mercantiles como Logroño se llevaban el vino en su viaje de retorno, abaratando costes y haciendo competitiva la producción local; los mercaderes, que actuaban como cambistas, facilitaban las operaciones de compra-venta; y al mismo tiempo, adelantaban dinero a los campesinos antes de la cosecha, permitiéndoles así hacer frente a los altos costes que suponían la cava y la vendimia ${ }^{37}$.

La burguesía mercantil acumuló enormes fortunas personales; prácticamente las únicas que había en la región a comienzos del XVI estaban en manos de mercaderes. En 1596, los mercaderes especializados en especias y paños tenían unos ingresos medios anuales de 1.265 ducados y los especializados en hierro y pescado de 2.167 ducados. Fortunas valoradas entre los 50.000 y los 100.000 ducados eran frecuentes. Cuando murió Diego Fernández Jiménez, un mercader lanero, dejó una deuda a su favor de 800 varas "de diferentes ropas" y 142.300 mrs. en metálico y otra deuda de 7.000.000 de mrs. en contra de Juan Pascual, otro mercader de quien hablaremos a continuación ${ }^{38}$.

Sus objetivos políticos y sociales no se limitaban a acumular dinero, querían además ascender socialmente, para lo cual les era fundamental ejercer cargos públicos ennoblecedores, municipales o reales. Una biografía puede servir para ilustrarlo. En torno a 1500 llegó a la villa de Torrecilla, Juan Paschoa, natural del valle de Zárate, dedicándose al comercio de la lana, entonces en plena expansión. Al crecer sus negocios se trasladó, en torno a 1530, a Medina del Campo. Para entonces ya había nacido su hijo Sebastián, al que le cambió el apellido vasco por el de Pascual. Cuando creció lo casó con una hidalga, Francisca Ruiz del Corral, vecina de Medina del Campo, que aportó al matrimonio viñas que producían unos 3.200 ducados al año, una auténtica fortuna. Sebastián ya comenzó el ascenso social, compró tierras, ovejas y accedió a un oficio real, aunque manteniendo los negocios de su padre:

"El trato que el dicho tuvo fue tener labranza y mucha granjería de ovejas y otros ganados, que de las lanas hacía sacas y enviaba a los puertos para que de alli las compraran los flamencos y así sustentó su casa, como hombre principal, con muchos criados. Y después se

36. Los datos sobre exportación lanera proceden de LAPEYRE, H., 1981: 347,270-273 y 289-291. Los datos de 1591 proceden de Archivo General de Simancas, Exp. Hacienda, $801 \mathbf{n}^{\circ} 12$.

37. Cfr., TORREALBA DOMÍNGUEZ, G., 1989.

38. BURGOS ESTEBAN, M., 1994. 
fue a Medina del Campo, donde fue Tesorero de las Salinas y Administrador dellas, y se le vio desde entonces venir a este lugar (Torrecilla) con mucha gente de a caballo"

Su hijo Juan —el mercader citado anteriormente- dará el siguiente paso: primero consiguió el cargo de Pagador de las Guardias de Castilla y después, en torno a 1580, se le designó como oidor del Consejo de Hacienda, llegando en 1600 a ser caballero de Santiago. No había olvidado sus orígenes y por aquellas fechas llegó al pueblo de su padre y procedió a liberar a los pecheros de sus cargas y a establecer, de hecho, la indistinción estamental:

"El reconocimiento que había entre hijosdalgo y pecheros para distinguirlos unos de los otros era que los pecheros pagaban el chapín de la reina, martiniega, servicio real y moneda forera, y para el efecto se hacían padrones (...) y y Juan Pascual hizo merced al estado de los labradores de dejarles situada renta para pagar los dhos pechos, y tuvo inteligencia con las personas que a la sazón gobernaban esta villa de quitar los dhos padrones para que en ningún tiempo se hallasen calificadas las personas desta villa"39.

Los grupos de mercaderes supusieron, en todas partes donde fueron importantes, un freno para la tendencia bajomedieval de control de los concejos por parte de la pequeña nobleza local; propiciaron la instauración de élites locales muy abiertas; fueron, en suma, un motor de cambio social en las principales ciudades y villas de la región.

Frente a los poderosos y ricos mercaderes, en La Rioja no hubo una nobleza local capaz de imponerse hasta mediados del siglo XVI. Lo consiguieron gracias al apoyo real, que favoreció sus intereses a la hora de instaurar sistemas de gobierno: en Logroño, Navarrete y Nájera, centros con sólida tradición burguesa, sólo se pudieron imponer los privilegios nobiliarios - la llamada mitad de oficios - a mediados del siglo XVI; en otros lugares con mayor predominio de la burguesía mercantil hizo falta todavía más tiempo: en Torrecilla sólo se pudo conseguir en 1617. Con todo, el poder de los linajes hidalgos locales iba en aumento, no sólo por el apoyo que les prestaba la Corona ${ }^{40}$, sino también por una nada escrupulosa política matrimonial, que les llevó a emparentar con los principales mercaderes de la región, hasta formar, a finales del siglo XVI, un único grupo social ya netamente nobiliario, puesto que las fortunas acumuladas con los negocios se invertirán en tierras y censos, amayorazgándose rápidamente, y el acceso a la nobleza reorientará todo el comportamiento social y político de los antaño inquietos mercaderes ${ }^{41}$.

La diversidad social era especialmente intensa en las ciudades del valle del Ebro. Las profesiones liberales, trabajando al servicio de las instituciones monárquicas Tribunal del Corregidor, alcaidías, Inquisición, aduanas - o eclesiásticas — tribunal del Obispado, parroquias, conventos - y colaborando en la administración de los

39. A.H.N., Ordenes Militares, exps. Calatrava 1332 y Santiago 6278

40. Sobre la consolidación de oligarquías protegidas por la Corona y los instrumentos del Estado, vid. GÓMEZ URDÁÑEZ, J.L. y LORENZO CADARSO, P., 1993.

41. Cfr., para el estudio de un caso concreto, M. BURGOS ESTEBAN, F., 1989: 91-117. 
señoríos o de los grandes mercaderes, serán también un grupo social dinámico e inquieto - la sublevación comunera de Nájera, por ejemplo, será dirigida por un bachiller-. Muy a menudo estaban emparentados con los linajes de mercaderes: los Arbieto fueron escribanos, los Moreno, administradores del duque de Nájera, los Soto, Tesoreros de la Merindad de Logroño, y así un largo etcétera, porque el ejercicio de profesiones liberales era también un excelente mecanismo de ascenso social y ennoblecimiento.

La plebe urbana estuvo constituida, como fue habitual en Castilla, por artesanos, pequeños propietarios agrarios, jornaleros y grupos marginales. En las principales ciudades, sobre todo Logroño, Nájera y Calahorra, algunas artesanías de productos de lujo, permitieron una situación social desahogada, como era el caso de los batidores de oro, plateros, armeros, impresores o artistas. Otras profesiones artesanales, sin embargo, no ayudaban mucho a salir de la pobreza, bien por presentar altos índices de proletarización, como era el caso de los curtidores o de los albañiles, bien por estar destinadas a un consumo popular, como los artesanos del textil, los zapateros, los alpargateros, e incluso por estar socialmente descalificadas, como los carniceros.

A pesar de ser un lugar de paso para los viajeros que entraban a Castilla y de haber un importante trasiego de mercancías - exportación de vino al País Vasco, Cameros y Castilla e importación de pescado, productos europeos, trigo, etc.--, había pocos trajineros en las ciudades; la mayoría eran campesinos residentes en los pueblos que trabajaban esporádicamente como arrieros. Lo que sí había en la principales ciudades era un elevado número de mesoneros y posaderos para atender a los transeúntes - -en Logroño, a fines del XVI, había más de 30-. El trasiego de gentes también propiciaba el aumento de los grupos marginales, emigrantes vascos y extranjeros sin recursos, prostitutas, vagabundos, etc.. El Ayuntamiento de Logroño tuvo siempre como una de sus prioridades controlar este flujo de personas en busca de fortuna, creando desde fecha muy temprana un oficial municipal encargado de vigilar la situación y dictando periódicamente órdenes de expulsión de la ciudad.

Los moriscos formaban comunidades rurales cerradas; en esta época ya sólo perduraba la de la villa de Aguilar de Río Alhama y algunas dispersas por los pueblos de la tierra de Cervera. Pertenecían al señorío de Aguilar, el cual les permitió contar con sistemas de gobierno propios - tenían sus propios alcaldes- y, según los representantes del rey, también les brindó protección frente a la hostil mayoría cristiana. Mantenían constantes relaciones personales y económicas con los moriscos aragoneses del otro lado de la frontera, como lo prueban las pesquisas contra el contrabando que se hacían periódicamente. En las grandes ciudades y villas con un sector mercantil potente, como Logroño, Haro o Nájera, tampoco era rara la presencia de moriscos, pero ésta nunca pudo ser importante debido a la política hostil que los concejos mantuvieron hacia ellos. En Logroño, por ejemplo, sólo podían permanecer si estaban siendo procesados por la Inquisición, siendo habituales las órdenes de expulsión de los que intentaban quedarse después o de sus familiares. 
Los judíos son mucho más conocidos y tenían además una presencia en la región cualitativa y cuantitativamente mayor ${ }^{42}$. Hasta el progrom de 1391, las comunidades judías riojanas eran eminentemente urbanas; según el famoso Repartimiento de Huete había ocho grandes juderías en La Rioja, radicadas en las principales poblaciones: Calahorra, Haro, Nájera, Logroño, Albelda, Alfaro, Arnedo y Cervera. Tras la victoria de los Trastamara frente a Pedro I se produjeron las primeras fugas masivas de judíos desde las ciudades hacia los núcleos rurales de señorío - Mansilla, Ausejo, Laguna de Cameros, Entrena- o incluso hacia Navarra, pero fue 1391 la fecha clave. La tolerancia medieval hacia la minoría judía, concretada en los propios fueros (Nájera) o en la ausencia de guetos hebreos (Logroño), se transformó en una persecución especialmente intensa en las ciudades, que vieron prácticamente desaparecer sus comunidades judías, bien por emigración, bien por conversión. "Derrámense mis lágrimas por Logroño...", decía una Quinah hebrea de $1391^{43}$. Las ocho grandes juderías urbanas de 1290 se habían convertido en unas ochenta en el momento de la expulsión, en 1492. Veamos algunos datos sobre esas juderías urbanas.

POBLACION
CALAHORRA
LOGROÑO
ARNEDO
ALFARO
HARO
NAJERA

\section{VECINOS JUDIOS}

$\begin{array}{cc}\frac{\mathbf{1 2 9 0}}{80} & \underline{\mathbf{1 4 9 1}} \\ 115 & 70-80 \\ 25 & 20-30 \\ 20 & 30-40 \\ 206 & \text { O } \\ 156 & 50-60 \\ & 30-35\end{array}$

El relativo crecimiento de la población hebrea riojana -718 vecinos en 1290 , 933 entre 1450 y 1479 y 877 entre 1486 y $1491^{44}$-, en el supuesto de que realmente se diera ${ }^{45}$, esconde una profunda crisis en el seno de la comunidad, las conversiones tuvieron que ser masivas y el alejamiento de los grandes centros comerciales tuvo que repercutir necesariamente en el nivel económico de la comunidad hebrea.

A partir de mediados del siglo XV la presencia judía en las grandes ciudades se limitará a los conversos, algunos de ellos, como los Montemayor de Navarrete o los Moreno y los León en Logroño acumularán enormes fortunas. Todavía a mediados del siglo XVI seguía viva en la memoria colectiva el fulgurante ascenso social de una

42. Cfr., CANTERA MONTENEGRO, E., 1987.

43. Cfr. PAGIS, D., 1968: 368, cit. en CANTERA MONTENEGRO, E., 1987: 492. Sobre las persecuciones, vid. Mac Kay, A., 1972: 33-67, y también en la colaboración de este autor en Historia de la Ciudad de Logroño, vol. II, en prensa.

44. Cantera MONTENEGRO, E., 1987: 67

45. Cantera Montenegro opina que a fines del XV había en Logroño entre 20 y 30 familias hebreas, sin embargo, y para que se vea la escasa fiabilidad de las cifras, en un padrón municipal de 1467 solo aparecen censados 12 judíos; Cfr. CANTERA MONTENEGRO, E. 1987: 69; Un estudio sobre dicho padrón municipal, hallado en Vitoria, ha sido recientemente publicado. Cfr. DÍAZ DE DURANA, J.R. y GARCÍA FERNÁNDEZ, E., 1991. 
familia logroñesa de conversos, a cuyo descendiente, ya apellidado Ponce de León, le cantaban una coplilla recordándole la condición de su abuelo:

\author{
"A ti te digo, Miguel, \\ hijo de Pedro Moreno \\ y nieto de don Bueno, \\ que yace en el moscatel" ${ }^{\prime 46}$
}

Miguel no sólo era hijo de un converso, sino que además era hijo natural, pero eso no le impidió ganar una ejecutoria de hidalguía en 1558 e iniciar así un proceso de ascenso social que culminaría tres generaciones después, cuando Luis Moreno, su bisnieto, logró ser caballero de Santiago en 1641 - gracias al apoyo, eso sí, que le ofreció el duque de Nájera-. Los vecinos podían ver todos los días la imagen viva de la fulgurante transformación, al entrar en la iglesia de La Redonda, la parroquia elegida por los "nuevos ricos" como símbolo — contra la más "popular" de Santiago o la vieja sede gótica de los hidalgos de San Bartolomé-, en la que junto a la puerta se hallaba la capilla de los Ponce de León.

A modo de conclusión general, podríamos decir que la sociedad riojana en torno a 1492 era ya altamente productiva - el rentismo era todavía patrimonio de la nobleza señorial y del clero-, relativamente abierta de cara al ascenso social, con unos sectores muy dinámicos, los centrados en el comercio y en la producción vinícola y textil, pero también con el germen de la crisis en su seno. El vino, el comercio de importación y la producción textil, los auténticos motores de esta sociedad, no podrían evitar un proceso de refeudalización generalizado, en el que las instituciones caerían en manos de una nobleza local cada vez más sólida: las grandes fortunas acumuladas en el comercio y el vino se invertirían en tierras y censos. A comienzos del siglo XVI La Rioja era tierra de grandes mercaderes con un pie en ella y otro en Flandes; un siglo después, sus descendientes vivirán de las rentas de sus mayorazgos, con un pie en La Rioja y otro en la Corte de Madrid. A partir de mediados del XVII se quedarán allí para siempre y las antaño prósperas ciudades se ruralizarán por momentos.

\title{
LA TRANSFORMACIÓN DE LAS INSTITUCIONES ANTE EL AVANCE DEL ESTADO
}

Las primeras claves de la evolución institucional que se consolidará a comienzos de la centuria hay que situarlas en el proceso de conquista, repoblación y fijación de la frontera, los acontecimientos fundamentales entre el siglo X y el XIII. En esos cuatro siglos se vivieron situaciones políticas y sociales muy diversas, que, en menor o mayor medida dejaron su impronta en la organización institucional de la región, desde muy temprano paralela a la castellana. 
La incorporación definitiva de La Rioja al ámbito de los reinos cristianos se lle vó a cabo en la época de Sancho el Mayor de Navarra. Serán él y sus sucesores quienes aporten los primeros embriones de organización institucional del espacio recién conquistado $^{47}$. La Rioja fue, hasta las conquistas de Alfonso VI, tierra de frontera, lo que dio lugar a la aparición del primer gran señorío territorial de su historia: el señorío de Cameros, otorgado por Sancho el Mayor a la familia Fortún para que organizara la defensa de los pasos fronterizos frente al peligro musulmán. La concesión terminaría por hacerse hereditaria y convertirse en un señorío laico propiamente dicho, permaneciendo en manos de la familia Fortún hasta el reinado de Alfonso XI, quien daría muerte con sus propias manos al último de sus descendientes.

También desde el mismo momento de la conquista surgirían una serie de monasterios con amplias concesiones territoriales: San Millán de la Cogolla ${ }^{48}$ y Santa María la Real serán los más poderosos. Posteriormente continuaría la fundación de monasterios rurales: Cañas, Sta. María de La Estrella, San Martín de Albelda, San Prudencio, Valvanera y otros ya en plena Rioja Baja.

Pero lo que realmente marcó la fisonomía institucional de La Rioja hasta el siglo XIV fue el conjunto de fueros y privilegios que consiguieron los concejos. Tanto los reyes Navarros como posteriormente los castellanos orientaron su política en tres grandes ejes: garantizar una frontera segura, propiciar la repoblación y potenciar el Camino de Santiago. Fue precisamente Sancho el Mayor quien reorientó el Camino de Santiago para hacerlo pasar por la parte sur de su reino, es decir, por La Rioja. El Camino dio lugar a una serie de poblaciones florecientes, transformando en burgos mercantiles antiguas villas agrarias (Logroño) y centros burocrático-eclesiásticos (Nájera ${ }^{49}$. Toda La Rioja Alta se articulará en torno a los poderosos concejos del Camino, ricos, privilegiados con fueros específicos y dueños de amplios señoríos concejiles: Logroño, Navarrete, Nájera y Santo Domingo —uno cada $15 \mathrm{Km}$. aproximadamente-

La concesión de fueros y privilegios se intensificó con la incorporación al reino de Castilla. Alfonso VI introdujo un fuero de origen navarro, el llamado fuero de francos, concediéndoselo a Logroño en el 1095, y que terminó extendiéndose por las principales villas y ciudades de La Rioja Alta (y luego del País Vasco): Navarrete, Santo Domingo, Nájera y Haro lo conseguirían posteriormente. El fuero de francos protegía a las comunidades frente a la nobleza señorial y garantizaba el libre desenvolvimiento de la economía concejil. A partir del siglo XI La Rioja será ya frontera de Castilla con Navarra, de manera que primarán las razones geoestratégicas a la hora de conceder privilegios y orientar la política real. Las principales villas se fortificaron ante el peligro navarro y prácticamente todas las importantes contaron con alcaides y guarniciones reales: Alfaro, Calahorra, Logroño y Navarrete, las más

47. Cfr., LACARRA, J.M., 1975.

48. Cfr., GARCÍA DE CORTÁZAR, J.A., 1976; y GARCÍA TURZA, J., 1990.

49. Cfr., GARCÍA DE VALDEAVELLANO, L., 1969. 
cercanas a la frontera, jugarían un importante papel en todas las disputas entre los dos reinos vecinos. A ello se deberá una segunda oleada de privilegios: concesiones territoriales sobre su entorno rural - Logroño incorporará en régimen señorial a Villamediana, Alberite y Lardero; Navarrete hará lo propio con Fuenmayor, Hornos de Moncalvillo, Sotés y Daroca-; privilegios de hidalguía colectiva (Alfaro); privilegios de no enajenación del realengo (Navarrete).

En conclusión, La Rioja era, hasta mediados del siglo XIV, una región constituida por poderosos concejos de realengo, salvo el enclave señorial de Cameros y las posesiones de los monasterios, que se radicaban también fundamentalmente en la sierra. La presencia del rey se limitaba al control militar de las principales fortalezas, cuyo aprovisionamiento de tropas era llevada a cabo por los propios concejos, como ocurría en Nájera, en Navarrete, en Alfaro y en Logroño, cuyo procurador mayor un cargo municipal- era el jefe de la milicia concejil encargada de la defensa de la ciudad.

Desde mediados del siglo XIV, con la llegada al trono de Alfonso XI, esta situación comenzó a sufrir un proceso acelerado de cambios. Al igual que sucedía en el resto de Castilla, la autoridad monárquica comenzó a hacerse efectiva en los municipios: delegados reales de todo tipo - los merinos reales y los pesquisidores- asumirán funciones ejercidas hasta entonces por los oficiales concejiles, el rey designará regidores y se impondrá en todas las localidades importantes el sistema de regimiento o de concejos cerrados. El reinado de los Reyes Católicos significará un impulso definitivo a este proceso. Las Cortes de 1480 permitieron la extensión a voluntad del monarca del sistema de corregidores, que asumen durante su mandato la representación del rey en sus distritos y, lo que es más importante, se apropian de una serie de funciones ejercidas hasta entonces por los concejos, la más importante de ellas, sin duda, la judicial ${ }^{50}$.

La presencia militar del rey se vio igualmente fortalecida. En La Rioja se creó la Capitanía General de la Frontera de Navarra, ejercida por el propio corregidor. Los cargos de alcaides, cuya escasa utilidad estaba ya más que probada, pasaron a ser títulos testimoniales. La milicias concejiles perdieron asimismo toda funcionalidad práctica. En este sentido, la constitución de la Santa Hermandad —en 1476- y su sometimiento a la autoridad directa del rey tendrá un papel fundamental. En La Rioja significó la desaparición de la vieja Hermandad antinobiliaria que agrupaba a catorce concejos desde 1358.

El despliegue territorial de la autoridad monárquica dio lugar a una nueva distribución administrativa ${ }^{51}$. Se crearon dos grandes merindades fiscales, la de Rioja con sede en Santo Domingo - y la de Logroño, que se repartían el conjunto del territorio. Hubo asimismo dos corregimientos, el de Santo Domingo y el de Logroño-

50. Para La Rioja, el único caso sobre el que hay publicaciones solventes es el del concejo de Logroño, Cfr. LORENZO CADARSO, P.L., 1989: 3-23; BAÑUELOS, J.M., 1987; y CANTERA MONTENEGRO, M., 1986: 5-39.

51. Cfr., ARMAS LERENA, N., 1989. 
Calahorra-Alfaro-Laguardia. El Adelantamiento de Burgos extendió su autoridad sobre la práctica totalidad de La Rioja Alta, teniendo una co-sede en Arenzana de Abajo. A efectos judiciales, los corregidores sólo tenían autoridad sobre la villa o ciudad en la que estuviese radicada su sede y en las aldeas dependientes de ella, pero, como puede comprobarse, la Corona eligió como sedes todas las grandes localidades de realengo, aunque para ello hubiera de valerse de la argucia legal de otorgar cuatro sedes a un mismo corregimiento.

A efectos jurisdiccionales podríamos dividir a La Rioja en tres grandes zonas: las de jurisdicción real directa — las sedes de los corregimientos_-, las de jurisdicción propia o municipal y las de jurisdicción señorial — que no eran sino una pequeña parte de las de señorío- . Todas ellas quedaban integradas en una jurisdicción única, la del rey, cuando los procesos judiciales pasaban de la primera instancia, momento en el que eran competencia de la Chancillería de Valladolid, reformada también durante el reinado de los Reyes Católicos, en 1480.

A partir de 1512, cuando Navarra sea incorporada a la Corona, la frontera perderá buena parte de su importancia militar, pasando a ocupar un primerísimo plano la cuestión económica y fiscal. La defensa militar de Castilla ya no se hará desde el propio territorio, papel que pasarán a desempeñar las fortalezas de Fuenterrabía y Pamplona. La Capitanía General de la Frontera, con sede en Logroño, perdía también buena parte de su importancia, ya que el grueso de las tropas estaban siempre al mando del Virrey de Navarra. La frontera fue, pues, una barrera casi exclusivamente fiscal, creándose para controlar las relaciones económicas y cobrar los aranceles una serie de aduanas a lo largo de toda La Rioja Baja, en el río Ebro y en Agreda. La más importante de ellas será la de Logroño, mejor radicada geográficamente por contar con un puente sobre el Ebro y estar en la misma frontera de las Provincias Exentas y Navarra; además, contaba con más privilegios fiscales y era el centro administrativo que concedía los permisos de sacas, la sede del corregidor.

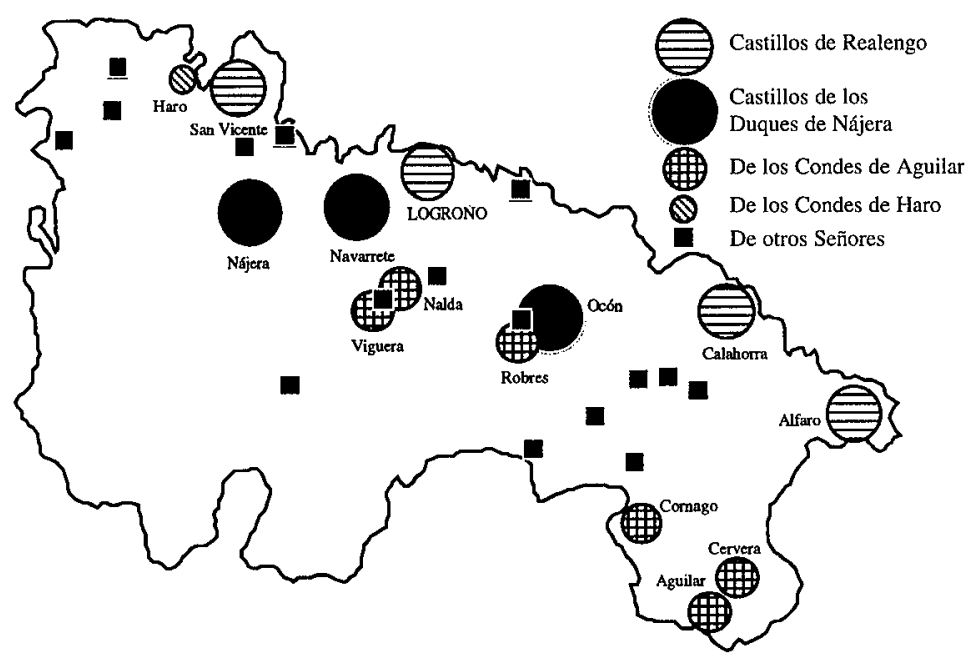

Los castillos más importantes en La Rioja en el XVI. En la frontera del Ebro, los del rey; en el resto de la región, el dominio del castillaje señorial es absoluto. 
El segundo gran factor que contribuirá a la modificación del marco institucional heredado será la extensión de los señoríos en los dos periodos ya clásicos: los reinados de Enrique II y Enrique IV ${ }^{52}$. Tras estas dos grandes oleadas de señorialización sólo permanecerán dentro del realengo una pequeña parte de los concejos del valle: Santo Domingo, Logroño, Calahorra y Alfaro ${ }^{53}$. El resto pasarán a depender de señores laicos, pertenecientes en su mayoría a la alta nobleza. Los principales beneficiarios serán los Ramírez de Arellano, condes de Aguilar, a quienes Enrique II concederá el antiguo señorío camerano de los Fortún, pero ampliando su extensión generosamente. Los Manrique de Lara, condes de Treviño, se llevarán dos de las villas más prósperas de la región, Nájera y Navarrete, importante centro mercantil la primera y gran productora de vino la segunda ${ }^{54}$. Los Condestables de Castilla se harán con otra de las grandes villas, Arnedo. La señorialización no siempre se hizo aprovechando las mercedes reales, antes bien cabría decir que éstas sólo supusieron el punto de arranque de todo un proceso de reforzamiento señorial que no cesaría, al menos por lo que respecta a los señoríos riojanos, hasta finales del siglo XVII. Incluso en algunas ocasiones se llevaron a cabo apropiaciones de jurisdicción sin más título que el uso de la fuerza. Fuenmayor, dependiente del señorío concejil de Navarrete es un excelente ejemplo. Cuando Navarrete cayó en manos de los duques de Nájera, en 1417, los señores de Almarza, aprovechando la debilidad del concejo de Navarrete, comenzaron una sigilosa estrategia de apropiación de jurisdicción valiéndose de que sus vasallos procedentes de Almarza lo seguían siendo en Fuenmayor:"...después, sigilosamente, poco a poco, fue trayendo más renteros de Almarza", hasta terminar, unos años después, autoproclamándose señores de Fuenmayor y "de hecho y por violencia quitar la vara al alcalde ordinario de la villa, suponiendo le tocaba a él el nombramiento"s5.

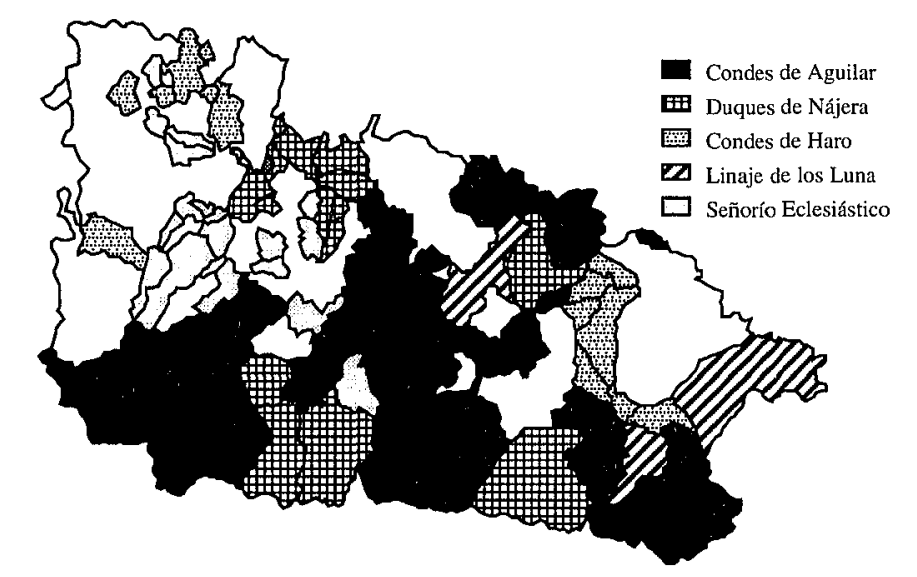

Los grandes señoríos de La Rioja, conformados ya en el siglo XIV

52. Cfr., MOXO, S. de., 1964: 185-236.

53. Cfr., LEZA, J. de, 1955 y 1954.

54. En 1578 se calculaba su producción media anual en unas 200.000 cántaras, que unidas a las 100.000 de Fuenmayor, su aldea, hacían un total de 300.000. Cfr. A. H. N., secc. Consejos, leg. 37.891.

55. A.H.N., Consejos, lgs., 25.926 y 32.653. 
Las apropiaciones estuvieron a la orden del día durante el reinado de Enrique IV, momento que aprovecharon los señores para redondear las rentas cobradas en sus territorios. El duque de Nájera, los condes de Aguilar y el condestable de Castilla se apropiaron de las alcabalas reales e impusieron duras cargas señoriales a sus $v$ asallos. El duque de Nájera, por ejemplo, se apropió de la fortaleza de la ciudad, del nombramiento de alguacil mayor, alcaldes, regidores, escribanos, procuradores, del cobro del portazgo, de la caza, de la pesca y de diversos términos comunales ${ }^{56}$. En Navarrete les comenzó a exigir 30.000 mrs. anuales de pedido, 25.000 por el nombramiento de merinos y 20.000 por el de escribanos; les impuso también algunos personales como el hospedaje, el acarreo, las azofras y el servicio militar en su escolta; por último, les exigía un presente de gallinas, capones, cebada y vino, se apropió de la leña de los montes, de la caza y de las rentas del señorío concejil de la villa, incluso impuso un impuesto especial sobre los productos que se traían a vender, el castillaje $^{57}$. Procesos similares al del ducado de Nájera ocurrieron en casi todos los concejos dependientes de la alta nobleza.

A finales del siglo XV y principios del XVI la situación era ya altamente conflictiva, sobre todo en las grandes localidades, que contaban con élites locales relativamente poderosas y ricas, con intereses políticos y económicos incompatibles con la dependencia señorial ${ }^{58}$. El eco que encontró la rebelión comunera en Haro y Nájera fue un aviso claro de cual era la situación ${ }^{59}$. Cuando cesó la represión y la situación política se calmó, la práctica totalidad de los señores riojanos tuvieron que hacer frente a una oleada de pleitos antiseñoriales, acompañados de frecuentes actos de rebeldía, ataques a sus representantes y negativas a seguir pagando las cargas impuestas en el periodo anterior. El siglo XVI fue pues un momento clave en la historia de los señoríos riojanos, no sólo porque la oposición popular se haría ya crónica durante todo el Antiguo Régimen, sino fundamentalmente porque los vasallos tuvieron un éxito relativamente alto, que llevaría a la quiebra a buena parte de la nobleza señorial a mediados del siglo XVII. Dos de las tres grandes casas presentes en La Rioja eran insolventes a mediados de siglo, los condes de Aguilar y el Condestable, y si los duques de Nájera pudieron hacer frente a sus obligaciones financieras fue gracias a una afortunada estrategia matrimonial ${ }^{60}$.

De cualquier modo, la combinación de ambos factores —aumento de la presión señorial y mayor presencia de la autoridad monárquica - produjeron cambios definitivos en los concejos, tanto en sus sistemas de gobierno y de organización administrativa como en su relación con respecto a los poderes superiores.

56. A.H.N., Consejos, leg. 32.738

57. A.H.N., Consejos, leg. 25.742

58. Cfr. MONTOJO, V., 1989: 53-66.

59. Cfr., GUTIÉRREZ NIETO, J.I., 1976.

60. Para la quiebra de los condes de Aguilar, Cfr., REINARES MARTÍNEZ, E., 1986: 76-97; para el caso de los duques de Nájera, Cfr., RUIZ TORRES, P., 1981. A nivel general puede verse YUN CASALILLA, B., 1985: 443-471; JAGO, Ch., 1982. En La Rioja, se puede consultar, aunque se refiera al siglo XVIII, GÓMEZ URDÁÑEZ, J.L. y ARMAS LERENA, N., 1994. 
El punto de partida, es decir, el funcionamiento de los concejos antes del siglo XIV, sólo lo conocemos a través de referencias esporádicas y poco precisas, aunque se puede reconstruir en sus grandes líneas presuponiendo su similitud con los castellanos y, en igual medida, con los navarros y vascos, que habían servido muy a menudo de modelo. Todo parece indicar que la práctica totalidad de los municipios se regían con diversos sistemas de concejos abiertos, subdivididos en asambleas de barrio (Logroño) o plenarios (Alfaro), celebrados cada vez que se debía tomar una decisión trascendente y, de modo ordinario, una vez al año para elegir alcaldes y procuradores y repartir los impuestos; así se hacía con seguridad en Calahorra.

El destacado papel que jugó la monarquía en la liquidación de estos sistemas de gobierno local queda bien a las claras en el caso de Logroño: Juan II impuso los concejos cerrados y la figura de los regidores; los Reyes Católicos suprimieron a los alcaldes ordinarios electivos sustituyéndolos por el corregidor, y más tarde, en 1496, establecieron la distinción estamental entre los cargos electos, reservándose un 30\% de ellos para cada estamento - había tres, hidalgos, labradores y ciudadanos-; en 1512 Fernando el Católico accedió, a petición de los representantes populares, a instaurar un sistema de gobierno de origen alavés en el que el concejo era regido por unos diputados elegidos en las asambleas de los quiñones; en 1541 se suprimiría al perpetuarse los regimientos, liquidándose así los últimos vestigios del sistema tradicional de gobierno. La evolución es clara: de un sistema de gobierno asambleario y con cargos representativos se pasa a un concejo oligárquico sin ningún tipo de control popular. Este proceso no sólo se debió a la acción de la Corona, sino que contó con el apoyo de los vecinos más ricos y poderosos, con los que podemos denominar elite local. Esto explica que en algunas localidades, con élites menos consolidadas, se mantuvieran algunos rasgos tradicionales, como es el caso de Calahorra, donde se seguía celebrando un concejo abierto cada año, aunque ya sólo fuese para decidir el modo de cobrar los impuestos ${ }^{61}$.

En las localidades de señorío también se dejó notar la intervención de la Corona, sobre todo en la reserva de oficios a la nobleza local y en la imposición de los concejos cerrados, incluso con perpetuaciones de regimientos. Pero, como era de esperar, fue la nobleza señorial la principal responsable de la liquidación de los sistemas tradicionales de gobierno. Navarrete y Nájera, enajenadas en 1417 y 1467 respectivamente, vieron como eran suprimidos sus alcaldes ordinarios electivos, pasando a desempeñar sus funciones un alcalde mayor designado por el señor. En Nájera el duque se contentó con designar a los regidores y demás oficiales entre los dos candidatos que los vecinos ofrecían para cada cargo, pero en Navarrete intentó designarlos directamente, aunque manteniendo el formalismo de las elecciones:

"Estando sus partes - decían los vecinos-en uso y costumbre inmemorial de entrar en los ayuntamientos a elegir regidores y oficiales del concejo, el duque, de pocos años a aquella parte, por fuerza y contra su voluntad, hacía a su alcalde mayor que entrase en los dichos

61. El proceso en Logroño, en GÓMEZ URDÁÑEZ, J.L., 1994-95: vol. III, Las nuevas formas políticas. 
ayuntamientos y no les dejase elegir libremente, antes les compelía a que nombrasen y eligiesen los oficiales que él quería"62.

Con todo, la crisis del municipio castellano -como la definió A. Domínguez Ortiz- estaba todavía lejos a comienzos del siglo XVI. Los concejos eran económicamente solventes y la oligarquización de la vida pública no había hecho sino dar sus primeros pasos. Esto era especialmente cierto en Cameros y en La Rioja Baja, donde persistían amplios territorios dedicados a un uso comunal, para pasto de las ovejas en Cameros, mientras que en La Rioja Baja predominaba la cría de animales de labor bueyes, yeguas, asnos y mulos - y se dedicaban las mejores tierras comunales a la explotación agraria. La expansión agraria tampoco había hecho sino comenzar, de modo que las concordias de riego entre los pueblos ribereños de los distintos ríos y las comunidades de pastos eran respetadas casi siempre. Más tarde, desde mediados del siglo XVI, las disputas entre concejos por el reparto del agua y de los pastos provocarían auténticos conflictos armados entre villas: Logroño contra Villamediana por los pastos del Iregua y contra Nalda, Navarrete, Entrena y Fuenmayor por el agua de riego; Ribafrecha contra Clavijo y Lagunilla por los pastos; Alfaro contra Cervera, Fitero y Cintruénigo; la lista podría ser interminable. Logroño llegó a atacar militarmente Nalda e Islallana en $1547^{63}$ y Calahorra, a comienzos del XVII, cambió con sacos terreros el curso del Ebro para aumentar su territorio $\mathrm{y}$, según los vecinos de Azagra, para intentar que la riada se llevase su pueblo ${ }^{64}$.

A medio camino entre lo civil y lo eclesiástico se encontraba el Tribunal de la Santa Inquisición. Desde su fundación en 1478, se constituirá como una institución dependiente directamente de la Corona, pasando a ser uno más de los Consejos reales - Consejo de la Suprema Inquisición, creado en 1488-. Esta dependencia no será solamente funcional, sino que será también la Corona quien vaya ampliando sus objetivos y su despliegue territorial hasta convertir al Santo Oficio en un instrumento más para fortalecer al Estado Absoluto. Fue precisamente el Tribunal de la Inquisición de Navarra el único organismo que extenderá su autoridad por toda La Rioja en su conjunto, aunque en un primer momento su sede todavía no estará fijada, pasando por Durango, Osma, otra vez Durango, Pamplona, Estella, Tudela y por fin, en 1523, Calahorra, ya en La Rioja, encontrando su sede definitiva en Logroño en $1570^{65}$. La razón de ser de este tribunal, que extenderá su distrito por toda $\mathbf{L a}$ Rioja, Navarra, País Vasco, Montes de Oca en Burgos, Santander y noreste de Soria, tendrá un objetivo adicional: servir de filtro en las relaciones entre Castilla-País Vasco-Navarra y sus vecinos franceses y aragoneses ${ }^{66}$.

62. A.H.N., Consejos, leg. 25.742

63. Este y otros conflictos por el agua, en LORENZO CADARSO, P.L. y GÓMEZ URDÁÑEZ, J.L., 1994-95: El tránsito hacia la modernidad; Las convulsiones sociales y políticas durante el siglo XVII. Sobre los regadíos, vid. LÓPEZ ARROYO, J., 1994.

64. El interesante conflicto, revivido en la actualidad, cuando se producen avenidas del Ebro, en A.H.N., Consejos, 29.611.

65. Cfr., ZINSKO GARMENDIA, B, 1987: 57-63.

66. Cfr., CONTRERAS, J. y DEDIEU, J.P., 1980: 37-93. REGUERA ACADO, I., 1978: 585-607. SANTA MARÍA Y GARRALETA, J.L., 1980: 405-410. 
En Calahorra primero y en Logroño después estarán los tres jueces del Tribunal, los fiscales, la cárcel, los órganos centrales ejecutivos, pero el control social ejercido por la Inquisición se llevará a cabo a través de una tupida red de familiares - informadores laicos - y comisarios - eclesiásticos - y de periódicas visitas de control llevadas a cabo por los jueces del Tribunal ${ }^{67}$. El objetivo declarado de todo el sistema inquisitorial era asegurar un riguroso cumplimiento de la ortodoxia católica, pero, realmente, acabó en un instrumento formidable de control social, en una sociedad en que "pecado y delito se confunden hasta convertirse en uno" y en la que la Inquisición acabó consolidándose como un centro más de poder ${ }^{68}$. Veamos algunos datos globales sobre la actividad represora en todo el distrito:

\section{PROCESOS 1582-1635 ${ }^{69}$}

$\begin{array}{lcc}\text { D E L I T O } & \text { NUMERO } & \text { \%DEL TOTAL } \\ \text { LUTERANOS } & 224 & 9,6 \\ \text { MORISCOS } & 481 & 20,6 \\ \text { BRUJERIA } & 140 & 6,0 \\ \text { JUDAIZANTES } & 113 & 4,85 \\ \text { FORNICACION } & 366 & 15,67 \\ \text { MATRIMONIO-CELIBATO } & 125 & 5,35 \\ \text { BIGAMIA } & 85 & 3,65 \\ \text { SOLICITANTES } & 62 & 2,65 \\ \text { PALABRAS HERETICAS } & 288 & 12,35 \\ \text { BLASFEMIAS } & 257 & 11,0 \\ \text { FAMILIARES } & 77 & 3,3 \\ \text { PALABRAS CONTRA EL } & & \\ \text { STO. OFICIO } & 35 & 1,5 \\ \text { VARIOS } & 82 & 3,5 \\ \text { TOTAL } & 2.335 & 100\end{array}$

Cuantitativamente, las principales víctimas del Santo Oficio por acusaciones de herejía en La Rioja fueron los moriscos del señorío de Cameros, habitantes en su mayoría de la zona de Cervera del Río Alhama (165 procesados entre 1582 y 1610), seguidos muy de lejos por los provenientes de Haro (21 casos), Logroño (5) y Nájera (5); seguidos de lejos por los protestantes (224 casos, mercaderes extranjeros en su mayoría) y los judaizantes (113 casos). Pero frente a este tipo de delitos, que habían sido los que habían justificado la aparición del Tribunal, los más habituales son los cometidos por cristianos viejos, delitos de opinión como la blasfemia, las proposiciones heréticas y los insultos al Santo Oficio, o de comportamiento como la forni-

67. Cfr., CRISTÓBAL, M.A., 1987: 65-96.

68. CONTRERAS, J. y CRISTÓBAL, M.A., 1994: 71 y ss.

69. Los datos proceden de ZINSKO GARMENDIA, B., 1987: 62; pueden complementarse con los ofrecidos por HENNINGSEN, G., 1984: 207-225; ibid., 1977: 547-570; CRISTÓBAL, M.A., 1986: 83-90; SIMÓN DÍAZ, J., 1946: 89-119; y ibid., 1948: 83-96. 
cación -relaciones sexuales extramatrimoniales—y la bigamia. En suma, la principal labor del Santo Oficio no fue la lucha contra la herejía, sino una continuada labor de control social frente a cualquier tipo de disidencia ideológica, frente a la pervivencia de costumbres paganas — como la brujería - o de modos de expresarse, muy enraizados en las tradiciones populares, pero considerados inmorales por la ortodoxia católica.

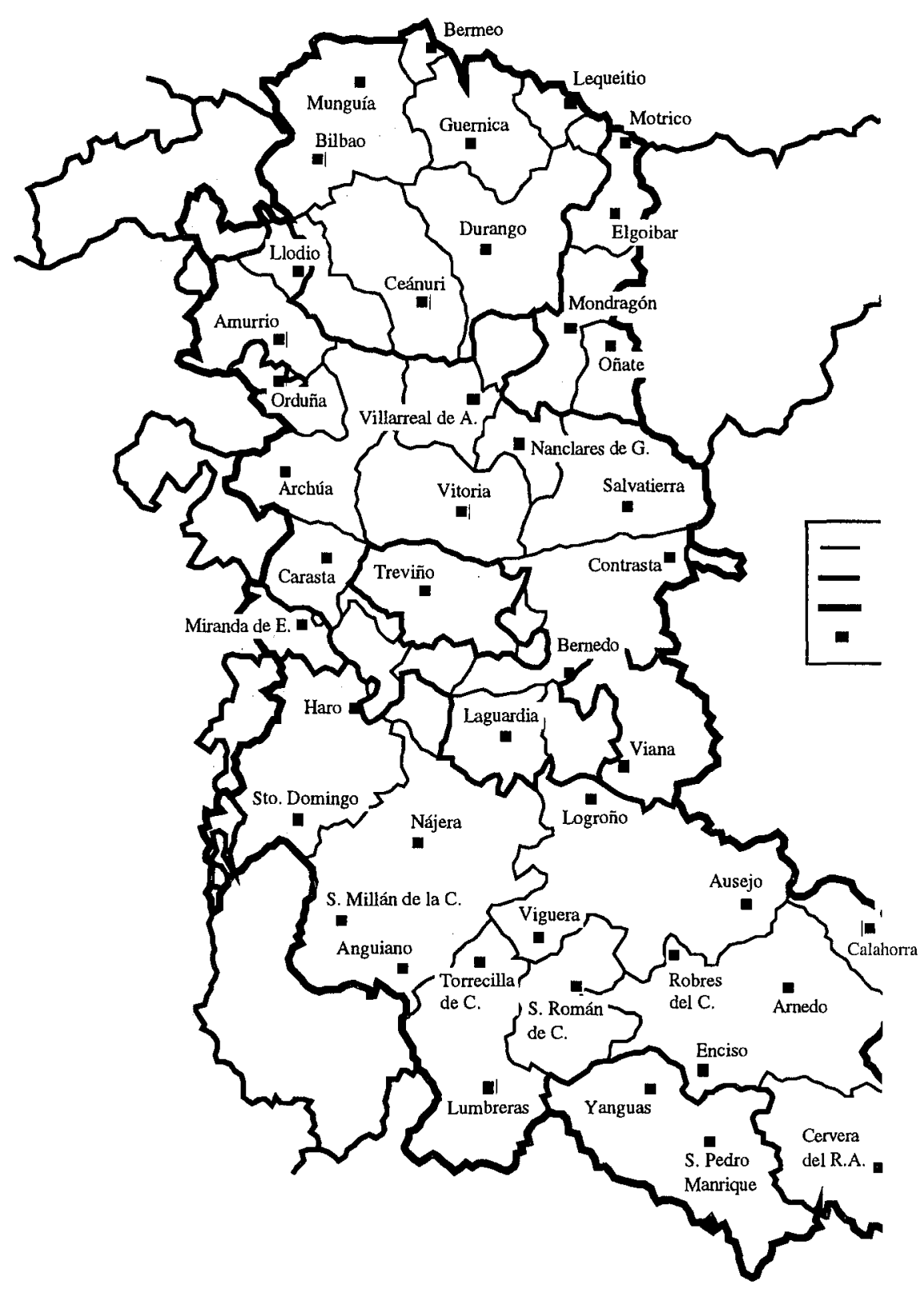

La diócesis de Calahorra y la Calzada hacia 1540

La Corona mantenía también un alto grado de autoridad sobre el clero secular, dado que un elevado porcentaje de las parroquias dependientes del Obispado de Calahorra pertenecían al Patronato Real. La práctica totalidad de La Rioja estaba incluida en el Obispado de Calahorra-La Calzada, salvo Alfaro, que dependía del 
Obispado navarro de Tarazona. Los grandes monasterios medievales ejercían su autoridad sobre un buen número de parroquias rurales, el de San Millán sobre las villas de su valle, el de La Estrella sobre San Asensio y San Vicente de la Sonsierra, el de San Prudencio sobre Lagunilla y Villanueva de San Prudencio, el de las monjas bernardas de Herce sobre Hornillos y algunas aldeas del más pobre Camero Viejo, y así un largo etcétera. Pero, el siglo XVI vio invertirse la tendencia: las nuevas órdenes del clero regular y algunas reformadas abandonan el campo para fundar en los núcleos urbanos. Los viejos monasterios medievales, con sus tradicionales métodos de percepción de rentas en sus dominios señoriales, se van quedando atrás frente a los métodos nuevos de los conventos urbanos, volcados a la inversión en tierras y a la percepción de donativos y dotes. A Enrique Cook, que acompañó a Felipe II en uno de sus viajes por La Rioja, no se le pasó desapercibida la abundancia de conventos en la ciudad de Logroño, entre los que cita el viejo de San Francisco, el de Santo Domingo, La Merced, los femeninos de Madre de Dios —el que un grupo de grandes mercaderes fundó para sus hijas ${ }^{70}$ - y Santa Clara y, desde luego, el de la Compañía:

"Y por ser la la comarca muy buena y rica, se encajaron también de poco tiempo acá los señores de la Compañia de Jesús, que por sus industrias buscan lo mejor y más gordo de la tierra"71.

La mayoría de las parroquias urbanas había sido erigida muy a menudo por los propios vecinos con el beneplácito real. Pertenecían pues al Real Patronato, pero lo más interesante era que las asambleas de parroquianos elegían por votación a los cargos rectores de sus parroquias y nombraban a los nuevos curas, exigiéndoles para ello que fuesen hijos de algún parroquiano. La autoridad del obispo se notaba poco en estos casos; la sede calahorrana se limitaba a cobrar su parte en el diezmo y a intervenir en algunos asuntos judiciales. Todas las parroquias de Logroño se regían por este sistema desde su fundación, pese a los constantes intentos del obispado por imponer su autoridad en el nombramiento de beneficiados. Con el tiempo, la autoridad episcopal se impondría, y sólo quedaría del sistema la libre adscripción de los vecinos a cualquier parroquia, como ocurría también en Arnedo ${ }^{72}$.

70. Los Enciso, los Yanguas, los Barrón, los Soria, enriquecidos con el tráfico internacional de lanas, dejaron la ciudad de Logroño poblada de recuerdos de su magnificencia hacia la iglesia: rejas, capillas, capellanías, etc., pero, preocupados por sus hijas, dotaron constantemente el convento de ricas de la ciudad, el de Madre de Dios, al que sólo se entraba pagando crecidas dotes. Cfr. AHPLo., Protocolos, leg. 504, f. 1 y ss.

71. Cfr. GARCÍA MERCADAL, J., 1952: 1.293 y ss. Sobre los conventos, IBÁÑEZ RODRÍGUEZ, S., 1994: 68 y ss. Sobre la fundación de la Compañía y su interés en la educación, RODRÍGUEZ SAN PEDRO, L.E., CARRASCO, A. y GÓMEZ URDÁÑEZ, J.L., 1994: 357 y ss.

72. Sobre las parroquias logroñesas, IBÁÑEZ, S., "Fundamentos de la vida parroquial logroñesa", 1994: 61-68. Sobre el final de la provisión electiva, LORENZO CADARSO, P.L., 1994. Sobre la libre adscripción en Arnedo, FERNÁNDEZ DE BOBADILLA, F., 1976: 372 y ss.; el autor se sorprende al comprobar la ausencia de territorialidad de las parroquias de Arnedo, que cree un caso único en España, a pesar de la cercanía a Logroño, donde ocurría lo mismo. 
En las parroquias con régimen electivo de provisión de plazas los cabildos tenían escasa capacidad de maniobra política en la ciudad, puesto que dependían de la población para conseguir ascensos. Estas parroquias terminaban por convertirse en una prolongación del resto de las instituciones municipales laicas, sujetas a los mismos conflictos que el propio concejo - los clérigos se veían obligados a condescender con la población en todo también por razones económicas, puesto que cada vecino podía hacerse parroquiano de la iglesia que desease, sin ninguna limitación por su lugar de residencia, de tal modo que el peligro de perder diezmeros estaba siempre presente- Otra cosa ocurría en parroquias como las de Calahorra, con cabildos fuertes al depender exclusivamente del Obispado. En estos casos los cabildos hacían frente al concejo y a los representantes del rey, inmiscuyéndose de manera habitual en todos los asuntos políticos locales.

\section{CONCLUSIÓN: PROPUESTAS PARA UN DEBATE}

La Rioja, la frontera nororiental del Reino de Castilla, es un buen laboratorio para observar los cambios sociales y económicos que afectaron al viejo reino en la centuria del Quinientos. La región, que presentaba excelentes condiciones para el crecimiento económico, produjo un cambio acelerado desde su adaptación temprana a las condiciones del mercado. Lana y vino, productos braudelianamente "capitalistas", propiciaron una red de comerciantes instalados en los grandes burgos a la salida de los valles que comunican el eje del Ebro con las sierras, volcados tempranamente al comercio regional —el vino hacia el País Vasco - y al comercio internacional - la lana y los textiles-, vía puertos del Cantábrico. El auge demográfico acompañó el proceso prácticamente hasta el fin de la centuria. Había hombres y capitales. La región aumentó en población y el dinero hizo famosas algunas ciudades, sobre todo Logroño y Nájera, donde los mercaderes marcaron la pauta. No obstante, el proceso se interrumpió. Ya antes del gran colapso de la peste finisecular, había señales. El viñedo, en cuanto que aumentaba, empezaba a ser un problema. Su rentabilidad dependía de la exportación hacia una única zona, de estructura social y económica muy peculiar, es decir, dependía de las condiciones en que se encontrara la región a la que se exportaba y de su capacidad para absorber el producto. Los años buenos producían una gran euforia; pero algunos años el vino no se vendía y provocaba la ruina de los pequeños productores y la desesperación de los jornaleros, como todavía vería Jovellanos a fines del XVIII y como se demostraría en los conflictos volcánicos de 1917 o 1934, protagonizados en los pueblos de la raya del Ebro - San Asensio, Briones, Cenicero- por desesperados pequeños viticultores y jornaleros del viñedo. Probablemente, la separación entre bodegueros, propietarios de medios de vinificación y almacenamiento — los privilegiados, clero e hidalgos, y algunos grandes productores, en el siglo XVI- y pequeños viticultores que tenían que vender la uva o hacer vino en pequeña cantidad en lagares y prensas arrendados - de favor, como se dice en La Rioja-, empezó a generalizarse en el siglo XVII. Pero el XVI fue el origen de esta peculiar estructura del viñedo, que se hacía más patente cuando arreciaban los malos tiempos — desde fines del XVIII, constantemente-y 
los grandes bodegueros, "que no tenían tierra ni para un tiesto", imponían los precios de la uva. Todavía hoy, sigue siendo éste el principal problema del Rioja: una pequeña red de vendedores de uva y una estructura de grandes bodegas de ricos propietarios - hoy, de capital multinacional - que imponen su ley.

Por eso, la riqueza de los grandes contrastaba con la pobreza de la gran proporción de jornaleros que imponía el cultivo de la vid. La viña se cultivaba por jornaleros, rara vez se daba en arriendo. La vinificación también empleaba abundante mano de obra asalariada, mientras la saca del vino mantenía un constante fluir de arrieros. Los pueblos vinateros se llenaban de temporeros, a un paso de ser considerados pobres en los malos tiempos; cuando la cosecha era mala o los precios bajaban, los concejos tenían que evitar el conflicto a toda costa, siempre vacilantes en el uso de la represión: imponían tasa a los jornales, amenazando con multas a los propietarios si la sobrepasaban, pero no la cumplían por temor a que la uva en sazón se quedase en la viña ${ }^{73}$. En tiempo de epidemias, se notaba más el nerviosismo: había que "cerrar" la ciudad como era tradicional, sin embargo, se hacía todo lo posible para no cortar el flujo de temporeros, hasta declarar que no había epidemia como se hizo incluso en la gran peste de 1599. En pleno mayo, el médico de Logroño hacía un informe en el que, a pesar de haber ya varios muertos, dice "paresció no ser peste la de la Ciudad de Logroño", con lo que pasa por ser un médico moderno, que ya había abandonado la teoría aerista y prefería la del contagio. Con todo, ni con la innovadora teoría reconocía la verdad, ya que "el contaxio no se comunicaba de una persona a otra"74.

Por otra parte, el mercado vasco había producido una zona competidora para la Rioja, el sur de Alava, La Rioja alavesa - y aun la ribera más occidental de Navarra-, contra la que había que defenderse de cualquier forma, incluso aumentando la superficie plantada, para aprovechar los años de malas cosechas. No se pensó en mejorar los métodos de vinificación —de ello no hay pruebas hasta finales del siglo XVIII-, que hacían que el vino no pudiera conservarse y que fuera un riesgo transportarlo. Muchos protocolos de venta especifican que el vino no ha de agriarse durante el viaje. El vino viejo y el reviejo valían menos que el del año. El negocio se protegió desde el poder, desde oligarquías consolidadas en los municipios, que desviaban los impuestos en la venta del vino, aunque tuvieran que cargarlos en las panaderías, carnicerías, abacerías, controladas — con renta, impuestos y fijación de precios - por los mismos concejos desde donde también partían las limitaciones de los salarios de los jornaleros y la imposición de precios del vino e incluso de sistemas de venta preferente. Estos también beneficiaban a los grandes cosecheros, con la disculpa de que la cuba abierta había que venderla para que el vino no se picase; claro que las cubas de los ricos eran más grandes que las de los pequeños productores. Al final, los pequeños vendían su vino en los portales de sus casas, al por menor. Curiosamente, esa es la razón de que Logroño tuviera pocas tabernas - en el siglo

73. Los conflictos jornaleros han sido estudiados por LORENZO CADARSO, P.L., 1994 y 1989: 81-96. y en su tesis, 1988. Hay suficiente suficientes pruebas de la aparición de formas de protesta y de una organización sorprendentes para la época.

74. H. A.P. Lo., Actas, Sesión de 31 de mayo de 1599, f. 40. Sobre la peste en Logroño, cfr. LÁZARO, M. y GURREA, P., 1994: 121 y ss. Sobre otras localidades, 1989. 
XVIII, ninguna, según el Catastro de Ensenada-: cada portal era una. Probar el vino de casa en casa se hizo una costumbre, el origen de nuestro chiquiteo, que todavía hoy perdura en torno a una calle enclavada en el barrio de los jornaleros y pequeños propietarios de los siglos XVI y XVII.

El problema del vino se sumó al de la lana a partir de la contracción del mercado castellano desde la década de los sesenta. La exportación descendió y se tornó más insegura. Sabemos todavía poco sobre la sierra en el XVI, pero todo hace sospechar que las pequeñas comunidades cameranas resistieron mejor aprovechado las rutas de la trashumancia, por las que no sólo pasaban ovejas, sino un surtido de productos que convertía a los serranos en pequeños comerciantes ambulantes. Algunos se iban quedando en los Extremos o saltaban a América, contribuyendo - sobre todo por la vía testamentaria- a inyectar capitales en la sierra ${ }^{75}$. Con todo, el comercio de los burgos pegados a la salida de los valles en el camino francés decayó. Desde ahora, la gran ruta castellana empezará a periclitar, mientras más al norte se abre una nueva, impuesta por la saca del vino hacia las Vascongadas, que desarrollará los ahora pequeños pueblos - Cenicero, Briones, San Asensio-, pero que ya en el XVIII marcarán la paúta del crecimiento económico en la región. Por ahí se abrirá el camino a Santander, auspiciado por la Sociedad Económica Riojana —otro ejemplo de proteccionismo de intereses vinateros-, el de Vitoria y, finalmente, el ferrocarril, las bases del desarrollo del Rioja y de la gran renovación de estructuras y técnicas.

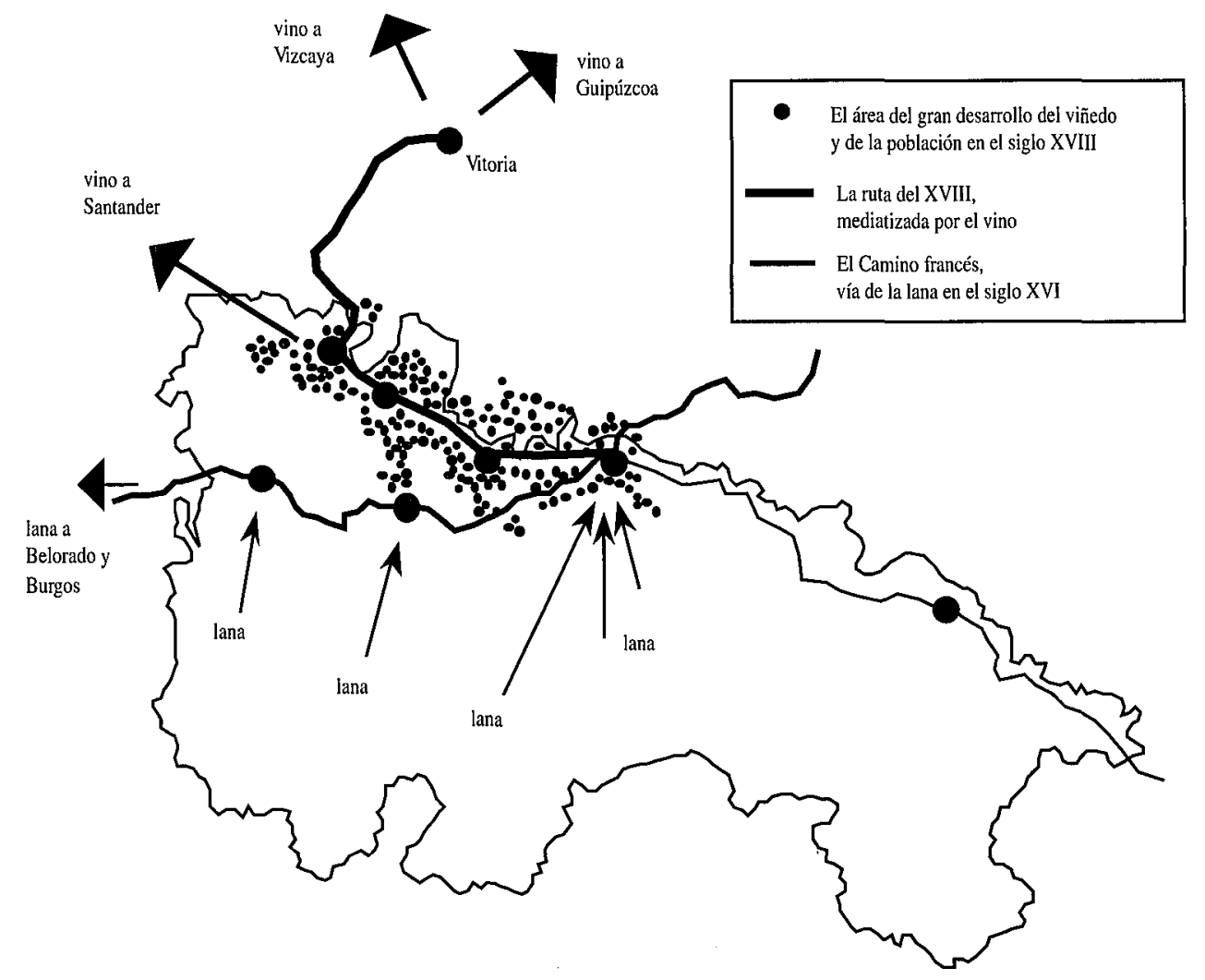

El cambio de tendencia en La Rioja Alta, en torno a las dos rutas de exportación más importantes

75. Cfr. ZULOAGA RADA, M., 1985: 91-100. 
Mientras, los extensos municipios de La Rioja Baja, siguieron anclados en la agricultura cerealera y en su complemento ganadero. Las manchas de viñedo en torno a Autol y Arnedo, relativamente extensas en el siglo XVI, se redujeron. El vino de esta zona estaba destinado a las sierras del Cidacos y del Alto Jubera, zonas muy pobres, sin otra posibilidad que la ganadería. Los pueblos de sierra baja como Munilla, Enciso, Zarzosa, etc. siempre practicaron menos la trashumancia, aunque tenían un fuerte contingente estante; como mucho, algunos rebaños bajaban al valle del Ebro, pero en cuanto aquí empezaba a crecer la población, se iban viendo expulsados de los pastos, cada vez más roturados para satisfacer la demanda de cereales. Los conflictos por las roturaciones son muy frecuentes, tanto en el siglo XVI como en la segunda mitad del XVIII, los momentos de mayor crecimiento demográfico. Disminuían los pastos y, a la vez, se reducía la superficie de viña, mientras aumentaba la de cereal y su complemento ganadero, pero autóctono.

El olivar, muy desarrollado en el siglo XVI, estaba también supeditado a la demanda serrana - aunque la mayor facilidad de conservación del aceite permitía un comercio más extenso que el del vino-, pero ocupaba tierras de mala calidad - recuérdese que el viñedo en la Rioja Baja es de regadío- y por eso resistió mejor; en el XVIII y, sobre todo, en el XIX, conocería una nueva expansión.

La emigración serrana hacia los grandes municipios acarrearía el despegue de la artesanía del textil basto, antes dispersa en la sierra, que, con el tiempo acabaría utilizando una materia prima alternativa a la lana: el cáñamo y el lino. Ya en el XVI, Cervera, Arnedo y algunos pueblos más pequeños como Murillo de río Leza producían gran cantidad de cáñamo y lino, lo que les permitía mantener un crecido número de tejedores que destinaban su producto a la venta en la región; pero sería en el XVIII cuando se generalizaría en torno a Cervera una potente industria de soguería y lienzos, en buena parte impulsada por la demanda de la Marina, y en torno a Arnedo y Munilla, las primeras artesanías del calzado, de la alpargata. Sólo la llegada del ferrocarril impulsaría la horticultura en el valle, muy desarrollada en el siglo XVI, pero sin posibilidades de expansión más allá del abasto de los grandes municipios como Calahorra, Alfaro, Agreda, Corella, etc. Probablemente, la obligada orientación de estas comarcas durante el siglo XVI a mantener el equilibrio entre ganadería y agricultura extensiva, - en la que la falta de agua y la menor proporción de regadíos jugó un papel esencial—, fue la causa de su anquilosamiento.

Pero, tan importante como el cambio de coyuntura internacional de la década de los sesenta del XVI es el problema social de fondo: desde el comienzo de la Edad Moderna, el gremio de mercaderes socialmente la difícil justificación de sus riquezas, lo que fue más notorio cuando cesó la coyuntura expansionista. Su origen "manchado" aparecía en cuanto había problemas. Contra eso, no tuvieron más remedio que ceder: lograron estrategias matrimoniales que les emparentaran con hidalgos, utilizaron las vías de la burocracia del Estado para colocarse en la corte 
$\mathrm{y}$, sobre todo, entregaron a la iglesia algunos de sus vástagos y buenos caudales. $\mathrm{E} 1$ caso de los Moreno, del que ya hemos hablado, es demostrativo: abuelo judío, hijo converso mercader enriquecido, que estrena nuevo apellido, Ponce de León, junto al de su padre; nieto, que sólo se apellida ya Ponce de León y que dona una de las capillas más ricas de La Redonda, para que en ella se entierre su hijo, que llegará a canónigo, después de haber obtenido la distinción de caballero ${ }^{76}$. Los Ponce de León llegarán a controlar regidurías perpetuas y a ser grandes propietarios de casas y tierras durante doscientos años más, pero sus actividades son típicas del rentismo; han abandonado el mundo del comercio y se han adaptado a vivir "honradamente" de las rentas que proporciona la propiedad. En definitiva, ellos mismos son el mejor ejemplo de cómo, en el siglo siguiente, sobrevendrá a esta región dinámica un largo periodo de "ruralización". En el XVI, el futuro parecía estar en las manos de aquellos mercaderes logroñeses y najerinos lanzados al comercio exterior, cuya riqueza andaba en papeles y especulaciones, pero que vivían en una ciudad, Logroño, en la que había dos imprentas —una de ellas, la del célebre Guillén de Brocar-y varios molinos de papel. En el XVII, las ciudades se dan tono con sus hidalgos, su abundante y ornamentado clero regular y parroquial, siempre a vueltas con las preeminencias y las jerarquías — para mayor industria de boneteros, sederos, tafetaneros, sastres, plateros, cereros, organeros y organistas, doradores y rejeros, ...-, y su nostalgia de Corte, en la que aspiraban a tener un miembro familiar que les sacara de apuros en sus interminables pleitos, aprovechando la cercanía de los burócratas ${ }^{77}$, pero ya Logroño no tiene más que una pequeña imprenta, que edita sobre todo catecismos y bandos ${ }^{78}$. Duraron en el poder, pero temían exhibir sus riquezas: no hay palacios ostentosos; sólo casonas de hidalgo con blasón. En Logroño, mantuvieron los regimientos perpetuos hasta 1801, cuando la situación era ya insostenible. Poco antes de llegar los franceses, en algunos pueblos vinateros se habían producido motines, como el que hizo huir de Briones al marqués de San Nicolás - cuyo hijo sería luego primer alcalde constitucional de Logroño durante el Trienio-; pero, allí mismo, en el Briones de las casonas hidalgas, del monopolio absoluto del viñedo, algunos hidalgos que dejaron la piedra sin labrar donde iba a ir luego el blasón que remataría la obra, nunca pudieron ver el sueño de su vida. Todavía hoy se pueden contemplar algunas de estas casonas con la piedra sin labrar.

76. La transformación no pasó desapercibida a la población. Ya hemos mencionado antes la coplilla que circuló sobre los orígenes de los abuelos. Otra, con la misma intención, ponía "en pasquines" a la familia Oviedo, de parecidos orígenes: Oviedo no andes más/ que harto dicen que anduviste/ cuando a Cristo condujiste/ de Pilatos a Caifás". Las referencias al origen judío son constantes y a veces motivan venganzas y desafíos de los que se sienten insultados. Cfr. GÓMEZ URDÁÑEZ, J.L. 1994-95: vol IV, cap. VIII.

77. Cfr. GÓMEZ URDÁÑEZ, J.L., 1994-95: III y t. IV, cap. VIII. Una visión general, 1994: 13 y ss.

78. Ramírez Bañuelos defenderá en breve su monumental tesis sobre la imprenta en Logroño. Un avance en su artículo, 1994. 
La Historia, arcano de la conciencia colectiva de los pueblos, no es sólo el pasado, ni desde luego una explicación del presente; es la eterna dialéctica que nadie como Quevedo ilustró en los célebres versos:

$$
\begin{aligned}
& \text { Aprended flores de mi, } \\
& \text { lo que va de ayer a hoy } \\
& \text { ayer maravilla fui } \\
& \text { y hoy, sombra mía no soy. }
\end{aligned}
$$

La historia de La Rioja es, como la de cualquier región, una invitación para meditar sobre lo que se ve todos los días. 


\section{BIBLIOGRAFÍA}

ALONSO CASTROVIEJO, J.J. 1992

Problemática agraria, solución burguesa, Logroño.

ARMAS LERENA, N. 1989

La organización institucional del concejo de Logroño, tesis de licenciatura inédita. Logroño.

BAÑUELOS, J.M. 1987

El concejo logroñés en los Siglos de Oro, Logroño.

BASAS FERNÁNDEZ, M. 1963.

El Consulado de Burgos en el siglo XVI, Madrid.

BRUMONT, F. 1984

Campo y campesinos de Castilla la Vieja en tiempos de Felipe II, Madrid.

BRUMONT, F. 1986

"La Rioja en el siglo XVI": Segundo Coloquio sobre historia de La Rioja, vol. II, 1170, Logroño.

BRUMONT, F. E IBÁÑEZ RODRÍGUEZ, S. 1994

"Una economía diversificada y en expansión": Historia de la Ciudad de Logroño, coord. Gómez Urdáñez, J.L., vol. III, 129-170, Logroño.

BURGOS ESTEBAN, F. 1989

"Las bases sociales del poder de la élite del estamento hidalgo. El linaje de los Barrón (Logroño, ss. XVI-XVII)": Brocar.Cuadernos de Investigación Histórica 15, 91-117.

BURGOS ESTEBAN, F. 1994

La élite nobiliaria de la ciudad de Logroño, tesis de licenciatura inédita, Madrid.

CANTERA MONTENEGRO, E. 1987

Los lazos del poder. Obligaciones y parentescos en una élite local castellana en los siglos XVI y XVII. Valladolid.

CANTERA MONTENEGRO, M. 1986

"El concejo de Logroño en tiempos de los Reyes Católicos (1475-1495)": Hispania $162,5-39$.

CARRETERO ZAMORA, J.M. 1994

"Logroño en la fiscalidad castellana del siglo XVI": Historia de la Ciudad de Logroño, coord. Gómez Urdáñez, J.L., vol. III, 229-244, Logroño.

CONTRERAS, J. Y DEDIEU, J.P. 1980

"Geografía de la Inquisición española. La formación de los distritos, 1470-1820": Hispania XL 144, 37-93. 
CONTRERAS, J. Y CRISTOBAL, M.A. 1994

"Logroño y el Santo oficio del Reino de Navarra: centro de control social, centro de poder": Historia de la Ciudad de Logroño, coord. Gómez Urdáñez, J.L., vol. III, 71 98, Logroño.

CRISTÓBAL, M.A. 1986

"La Inquisición de Logroño: mentalidad popular en el agro riojano": Segundo Coloquio sobre Historia de La Rioja, vol. II, 83-90, Logroño.

CRISTÓBAL, M.A. 1987

"La Visita de Distrito, medio de radicación del sistema inquisitorial de control social. El Santo Oficio de Logroño (1538-1613)": Brocar. Cuadernos de Investigación 13, 65-96.

DÍAZ DE DURANA, J.R. Y GARCÍA FERNÁNDEZ, E. 1991

Demografía y sociedad, la población de Logroño a mediados del siglo XV, Logroño.

DOMÍNGUEZ ORTIZ, A. 1983

Las clases privilegiadas en el Antiguo Régimen, Madrid.

FERNÁNDEZ DE BOBADILLA, F. 1976

Apuntes para la Historia de Arnedo, Arnedo.

GARCÍA DE CORTÁZAR, J.A. 1976

El dominio de San Millán de la Cogolla (siglos X-XIII). Introducción a la historia rural de la Castilla altomedieval, Madrid.

GARCÍA DE VALDEAVELLANO, L. 1969

Orígenes de la burguesía en la España medieval, Madrid.

GARCÍA MERCADAL. 1952

Viajes y viajeros por España y Portugal, Madrid.

GARCÍA TURZA, J. 1990

El monasterio de Valvanera en la Edad Media, Madrid.

GÓMEZ URDÁÑEZ, J.L. 1983

Historia de La Rioja, vol. III., Logroño.

GÓMEZ URDÁÑEZ, J.L. 1986

"Subsistencia y descapitalización en Cameros": Brocar. Cuadernos de Investigación 12, 105-140.

GÓMEZ URDÁÑEZ, J.L (COORD.). 1987

Cenicero Histórico, Transformaciones económicas y cambios sociales en una ciudad riojana, Cenicero. 
GÓMEZ URDÁÑEZ, J.L. Y LORENZO CADARSO, P.L. 1993

"Las Comunidades rurales frente al Estado Absoluto": Melanges de la casa de Velázquez, XXIX-2, 79-92.

GÓMEZ URDÁÑEZ, J.L. (COORD.). 1994-95

Historia de la Ciudad de Logroño, vols. III y IV, Logroño.

GÓMEZ URDÁÑEZ, J.L. 1994

"Aviso para caminantes por el Logroño del siglo de Oro, a manera de introducción": Historia de la Ciudad de Logroño, coord. Gómez Urdáñez, J.L., vol. III, 13-24, Logroño.

GÓMEZ URDÁÑEZ, J.L. Y ARMAS LERENA, N. 1994

Los Señoríos en La Rioja en el siglo XVIII, en prensa.

GUTIÉRREZ NIETO, J.I. 1976

Las Comunidades como movimiento antiseñorial, Barcelona.

HENNINGSEN, G. 1977

"El banco de datos del Santo Oficio. Las relaciones de Causas de la Inquisición española, 1550-1700": Boletín de la Real Academia de la Historia CLXXIV, 547-570.

HENNINGSEN, G. 1984

"La elocuencia de los números": Inquisición española y mentalidad inquisitorial, Alcalá, A., 207-225, Barcelona.

HUETZ DE LEMPS, A. 1967

Vignobles et vins du Nord Ouest de l'Espagne, Bordeaux.

IBÁÑEZ RODRÍGUEZ, S. 1991

Economía y sociedad en La Rioja (ss. XVI-XVIII), tesis de licenciatura inédita. Logroño.

IBÁÑEZ RODRÍGUEZ, S. 1994

"Fundamentos de la vida parroquial logroñesa": Historia de la Ciudad de Logroño, coord. Gómez Urdáñez, J.L., vol. III, 61-70, Logroño.

JAGO, CH. 1982

"La crisis de la aristocracia en Castilla del siglo XVII": Poder y sociedad en la España de los Austrias, J.H. Elliot (ed.), Barcelona.

LACARRA, J.M. 1975

Historia del reino de Navarra en la Edad Media, Pamplona.

LAPEYRE, H. 1981

El comercio exterior de Castilla a través de las aduanas de Felipe II, Valladolid. 
LAPEYRE, H. 1981

El comercio exterior de Castilla a través de las aduanas de Felipe II, Valladolid.

LÁZARO RUIZ, M; GURRÍA GARCÍA, P.A. Y ORTEGA BERRUGUETE, A.R. 1988 "La emigración vasca a La Rioja durante la Edad Moderna. Los Libros de Parroquianos de la ciudad de Logroño": Ernaroa 5, sept. 7-50.

LÁZARO RUIZ, M. Y GURRÍA GARCÍA, P. 1989

Las crisis de mortalidad en La Rioja (ss.XVI-XVIII), Logroño.

LÁZARO RUIZ, M. 1994

La población de la ciudad de Logroño durante el Antiguo Régimen (1500-1833), Logroño.

LÁZARO RUIZ, M. Y GURRÍA GARCÍA ,P. 1994

"Las cuentas de la vida y la muerte": Historia de la Ciudad de Logroño, coord. Gómez Urdáñez, J.L., vol. III, 121-128, Logroño.

LEZA, J. DE. 1954

Los Lope Díaz de Haro, señores de Vizcaya, y los señores de Cameros en el gobierno de La Rioja durante la Edad Media (1106-1334), Logroño.

LEZA, J. DE. 1955

Señoríos y municipios de la Rioja durante la Baja Edad Media (1319-1474), Logroño.

\section{LOPE TOLEDO, J.M.1958-59}

"Presencia y acción de La Rioja en América": Berceo 47, 173-196; 48, 251-268; 49, 405-423; 50, 7-24; 51, 151-168; 52, 279-301; 53, 407-430.

LÓPEZ ARROYO, J. 1994

Los regadíos en La Rioja, Logroño.

LORENZO CADARSO, P.L. 1988

Los conflictos sociales en Logroño en los siglos XVI y XVII, tesis de licenciatura inédita, Logroño.

LORENZO CADARSO, P.L. 1989

"El conflicto jornalero en Logroño (ss. XVI-XVII)": Berceo 116-117.

LORENZO CADARSO, P.L. 1992

Fray Juan Ramírez, obispo de Guatemala, inédito. 
LORENZO CADARSO, P.L. 1989

"Luchas políticas y refeudalización en Logroño en los ss. XVI y XVII": Historia Social 5, 3-23.

LORENZO CADARSO, P.L. 1994

"El final de las parroquias de provisión electiva": Historia de la Ciudad de Logroño, coord. Gómez Urdáñez, J.L., vol. III, 475-479, Logroño.

LORENZO CADARSO, P.L. 1995

"Las luchas jornaleras": Historia de la Ciudad de Logroño, coord. Gómez Urdáñez, J.L., vol. IV, 13-16, Logroño.

MAC KAY, A. 1972

"Popular movements and progroms in fifteenth century Castille": Past and Present $55,33-67$.

MELÓN, M.A. 1986

"De los Cameros a la Extremadura": Brocar. Cuadernos de Investigación 12, 141158.

MELÓN, M.A. 1989

Extremadura en el Antiguo Régimen, Mérida.

MENDIÓROZ LACAMBRA, A., RUIZ-NAVARRO PÉREZ, J., RAMÍREZ MARTÍNEZ, J.M. Y GÓMEZ URDÁÑEZ, J.L. 1995

"Las manifestaciones artísticas": Historia de la Ciudad de Logroño, coord. Gómez Urdáñez, J.L., vol. IV, 97-116, Logroño.

MONTOJO, V. 1989

"La formación de la oligarquía urbana de Cartagena a comienzos del siglo XVI": Gestae. Taller de Historia 1, 53-66.

MOXÓ, S. DE. 1964

"Los señoríos. En torno a una problemática para el estudio del régimen señorial": Hispania 94, 185-236.

OCHAGAVÍA, D. 1957

Historia textil riojana, Logroño.

PAGIS, D. 1968

"Elegías por las persecuciones del año 1391 en España": Tarbis XXXVII, 4, Jerusalem.

PEREIRA, J.L. 1983

"La monopolización de los pastos cacereños por los ganaderos castellanos en el siglo XVI": El pasado histórico de Castilla y León vol. II, 127-139, Burgos.

RAMÍREZ BAÑUELOS, J.M. 1994

"Las papeleras y la imprenta: dos historias paralelas": Historia de la Ciudad de Logroño, coord. Gómez Urdáñez, J.L., vol. III, 397-408, Logroño. 
JOSE LUIS GÓMEZ URDÁÑEZ

REGUERA ACADO, I. 1978

"Los comienzos de la Inquisición en Navarra": Príncipe de Viana 152-153, 585-607.

REINARES MARTÍNEZ. 1986

"Municipio y rentas feudales en el Alto valle del Leza": Berceo 110-111, 76-97.

RODRÍGUEZ SAN PEDRO, L.E., CARRASCO, A. Y GÓMEZ URDÁÑEZ, J.L. 1994

"De las escuelas de Logroño a las Universidades": Historia de la Ciudad de Logroño, coord. Gómez Urdáñez, J.L., vol. III, 357-376, Logroño.

RUIZ RIBERA, J. 1988

El Consulado de Cádiz, Cádiz.

RUIZ TORRES, P. 1981

Señores y propietarios. Cambio social en el sur del País Valenciano: 1650-1850, Valencia.

SALAS AUSÉNS, J.A. Y MAISO, J. 1976

"La población de Huércanos": Cuadernos de Investigación. Historia, II, 51-81.

SANTA MARÍA Y GARRALETA, J.L. 1980

"Orígenes de la Inquisición moderna en Navarra": La Inquisición Española: nueva visión, nuevos horizontes, Madrid.

SIMÓN DÍAZ, J. 1946

“La Inquisición en Logroño, 1570-1580": Berceo 1, 89-119.

SIMÓN DÍAZ, J. 1948

“La Inquisición en Logroño, 1580-1600”: Berceo 3, 83-96.

SIMÓN DÍAZ, J. 1952

"Otro romance sobre desgracias logroñesas": Berceo 23, 243-252.

TORREALBA DOMÍNGUEZ, J.G. 1989

Infraestructura urbana y actividad mercantil en Logroño (1650-1750), tesis de licenciatura inédita, Logroño.

VIÑAS Y MEY, C. 1941

El problema de la tierra en la España del siglo XVI y XVII, Madrid.

YUN CASALILLA, B. 1985

"Aristocracia, señorío y crecimiento económico en Castilla: algunas reflexiones a partir de los Pimentel y los Enríquez": Revista de Historia Económica 3, 443-471.

ZINSKO GARMENDIA, B. 1987.

"El tribunal inquisitorial de Logroño": Brocar. Cuadernos de Investigación, 13, 57-63.

ZULOAGA RADA, M. 1985

"Emigrantes riojanos a América": Segundo Coloquio sobre Historia de La Rioja, vol. II, 91-100, Logroño. 